\title{
CONCEPTION, CONNOTATION, AND ESSENTIAL PREDICATION: \\ PETER AURIOL'S CONCEPTUALISM TO THE TEST IN II SENTENTIARUM, D. 9, Q. 2, ART. 1
}

Keywords: Peter Auriol, Connotation, Essential Predication, Conceptualism

\section{Introduction}

Peter Auriol's theory of cognition is undoubtedly the part of his thought which has been most thoroughly scrutinized by Medieval scholars. It is quite surprising, however, that one of the noetic tools which Auriol most insistently makes use of to shape his own position has managed to escape

* Giacomo Fornasieri-Ph.D. Università degli Studi di Salerno-KU Leuven. He is a postdoctoral fellow at Lumsa University in Rome (Italy), where he is working on a project devoted to Auriol's ontology, which includes the edition of significant parts of Auriol's Commentary on Book II of the Sentences. His recent works mainly focuses on Auriol's epistemology $(2018 ; 2021)$.

E-mail: giacomo.fornasieri@gmail.com.

I want to thank Monika Michałowska, Riccardo Fedriga, Costantino Marmo and the two anonymous referees for their comments and remarks. 
the attention of a great part of contemporary scholarship. ${ }^{1}$ This is the notion of connotation, which, in contrast, for example, with Ockham's detailed treatment, Auriol thinks of just as the semantic property of some terms to have a primary and a secondary signification which are in fact implied, so that one cannot think of the former without also thinking of the latter. The aim of this paper, then, is to show that Auriol's use of connotation as applied to intellectual cognition is fundamental to his moderate conceptualism, as it is presented, while partly taken for granted, in Auriol's Commentary on Book II of the Sentences, distinction 9, question 2, article 1. Such a paper, then, must be thought of as an introduction to Auriol's text and a discussion of the arguments there contained. To this purpose, the first part of this paper will be devoted to a brief presentation of Auriol's conceptualism. In the second part, Auriol's theory of essential predication will be presented. This task will be accomplished by taking into account an objection to Auriol's own view, which he himself discusses, as well as the answer he provides to it. In the third part, I will present my claim that Auriol's answer as well as his theory of essential predication can only make sense when read against the background of his theory of connotation as applied to intellectual cognition. Finally, I will offer a semi-critical edition of Auriol's Commentary on Book II of the Sentences, distinction 9, question 2, article 1.

\section{Auriol's Moderate Conceptualism}

One of the most fundamental claims of Auriol's ontology is that individuality is a primitive feature of reality: everything that exists, insofar as it exists, is an individual entity. ${ }^{2}$ The result of his radically lean ontology is that no essences, common natures or whatever form of universals in re are to be posited in the extra-mental reality. The world is solely made of singulars and, independently of the mind's act, numerical unity is the only form of real

1 Remarkable exceptions are Conti, 2000, pp. 99-116; Friedman, 2013; Halverson, 1998. For Auriol's employment of connotation within theological discussions, see Fornasieri, 2018, pp. 231-274; Paladini, 2018a, pp. 203-238; Paladini, 2018b, pp. 455498. On connotation as applied to intellectual cognition, see also Fornasieri, 2021.

2 Petrus Aureoli, II Sententiarum, d. 9, q. 3, art. 3 (ed. Fornasieri, 2019, vol. II, p. 50): "[...] omnis res eo quod est singularis est." On Auriol's treatment of individuality see Fornasieri, 2019; Friedman, 2000: Suarez-Nani, 2009. 
unity to be possibly given in the extra-mental reality. The task of this paper is to present a survey of Auriol's criticism of metaphysical realism and offer a discussion of his defense of the irreducible singularity of the extra-mental reality. ${ }^{3}$ What is central to my analysis, then, is to see how his moderate conceptualism is linked to his theory of essential predication and to his claim that intellectual cognition is a connotative notion. To give some more insight into this issue, I will show that, for Auriol, postulating the existence of a common nature simultaneously shared by each and every individual of a given species would inevitably mean for him to compromise both the unity and the unicity of primary substances, which instead is one of Auriol's most cared-for philosophical thesis.

This interpretation becomes apparent by pointing out just one of the arguments Auriol provides to reject realism and defend his claim about the primitive feature of individuality, as it is found in distinction 9, question 2, article 1 of his Commentary on Book II of the Sentences. The target of Auriol's criticism is a type of realism, which he does not hesitate to define "Platonic". It is not easy to discern whom (if any in particular) Auriol might have had in mind here, though. Upon closer inspection, one needs to make no particular efforts to realize that Auriol takes that label in a quite loose sense, that is, to refer even to a less extreme form of realism, which one would not immediately reduce to the genuine form of exaggerated realism attributable to Plato. Auriol, in fact, seems to think of as "Platonic" whatever doctrine, according to which the semantic values of our general terms (say: "animal", "human being", etc.) are some kind of F-ness really borne by and fully inhering in each and every individual belonging to the F species, independently of any cognitive act. In this regard, it is no coincidence that, in contrast to what one might expect, Auriol does not take the Platonic Ideas to be as something existing in a world of pure, fully existent forms, entirely detached from our contingent reality, but as something inhering in and still somehow different from the particulars in which it inheres. Upon these considerations, then, it seems that the most sensible reading of Auriol's words is that by "Platonism" here he is referring to a number of authors (multi), whose views share some basic philosophical theses, regardless of the specific differences that distinguish their theories. By "Platonism", in other

\footnotetext{
3 A full understanding of Auriol's view on the matter, as well as his criticism of realism can be easily obtained through the text in the appendix.
} 
words, Auriol seems to have in mind whatever kind of doctrine aims at granting some form of mind-independency to what is signified through our universal concepts. In this regard, Auriol's arguments should therefore be taken as addressed against not just an extreme, Platonic form of realism, but also against much more moderate forms of it. ${ }^{4}$

This view easily discloses once that Auriol's reasoning is taken into account. As he puts it: if something like a specific unity (i.e., common nature) were ever to exist in the extra-mental reality, as a feature indifferently instantiated in each individual of a given species, then essential predication (and thereby scientific knowledge) would never be possible. In fact, by granting the existence of a F-ness fully occurring in each individual of the F-species, a realist of the sort of which Auriol is dealing with here implies that that F-ness occurs in each of those particular entities (1) in its entirety and (2) independently of any cognitive act. ${ }^{5}$ Upon this view, then, F-ness would occur as something instantiated by and therefore identical with its own suppositum, while still being somehow distinct in each of the supposita in which occurs. ${ }^{6}$

${ }^{4}$ Petrus Aureoli, II Sententiarum, d. 9, q. 2, art. 1 (ed. Fornasieri, infra, pp. 107-108: 29-20). See also Petrus Aureoli, II Sententiarum, d. 9, q. 2, art. 1 (ed. Fornasieri, infra, pp. 114-115: 12-11). It is no coincidence that Auriol relies on Aristotle and the so-called "argument of the third Man" to support his own view against this form of realism. On this point and Auriol's use of Aristotle, see Petrus Aureoli, II Sententiarum, d. 9, q. 2, art. 1 (ed. Fornasieri, infra, p. 110: 13-15).

5 See, for example, Petrus Aureoli, II Sententiarum, d. 9, q. 2, art. 1 (ed. Fornasieri, infra, pp. 107-108: 29-20; p. 109: 7-14; p. 110: 16-20).

6 When it comes to finding out whose opinion could have been the target of Auriol's criticism here, a good attempt is made by Cross, according to whom, Auriol's aim is undoubtedly Burley's opinion. The main reason for his claim is that the very same view Auriol presents here can be found in Burley's Tractatus de Universalibus (see Cross, 2014, pp. 214-215). Now, Cross is surely right in stressing this point, as there are some solid philosophical reasons in support of his thesis, such as Burley's endorsement for an exaggerated form of realism, which was generally considered by his contemporaries as Platonic. In addition to it, the fact that Auriol openly discusses Scotus's view in d. 9, q. 2, art. 2 seems to entail that, for him, Scotus's and Plato's views should be treated as definitely distinct theories, thereby excluding Scotus (a serious candidate for the title of "Platonic thinker") from the list of the "Platonists" Auriol is dealing with in article 1. Despite the evidence, however, some reservations still remain. First and foremost, Cross' attribution does not appear entirely convincing from an historical point of view. As Conti has effectively shown (see for example Conti, 2016), it is only 
However, Auriol claims that it is precisely at this point that some problems arise for this view. In particular, he raises the issue by asking the realist how the general term signifying a common nature should be predicated of the individuals to which that common nature belongs, which is to say, how that common nature should be deemed to occur in the individuals in which it said to occur. As Auriol claims, there are just two options available here: a common term signifying a common nature should be predicated of the

after 1324 that Burley shifts from a form of moderate toward a form of "Platonic" realism. More specifically, Burley's Tractatus de Universalibus seems to be placed after 1337. Since at that time Auriol had already concluded his lecturing on Book II of the Sentences about nineteen years previously, then, it would have been impossible for him to refer to Burley's specific opinion. As a result, if we really want to stay with Cross' thesis and thereby to claim that (one of) Auriol's target(s) here is Burley (which is not necessarily false), such a conclusion cannot be surmised from just Cross' own argument of a 'family resemblance' between the position Auriol rejects here and Burley's realism, as it is found in the Tractatus de Universalibus. Of course, the scattered evidence presented above to question Cross' attribution does not provide us with strong, positive reasons to claim once and for all that Auriol's target cannot be Burley: Auriol's reference is probably too vague to make univocal attribution. But here is my second point: I do not think that Auriol's target here must be Burley, as the type of realism Auriol is dealing with here might also apply, as has been shown, to a less extreme, or not-genuinely Platonic, form of realism. In fact, there are at least other thinkers, whose doctrines may indeed fall into Auriol's description. As Suarez-Nani also argues (see Suarez-Nani, 2009, p. 342), one of these cases is certainly Duns Scotus. Compare (as an example) the realist's arguments Auriol refers to here with Scotus's following text: John Duns Scotus, Ordinatio, II, d. 3, pars 1, q. 1 (ed. Balić, Barbarić, Bušelić, Hechich, Modrić, Nanni, Rosini, Ruiz de Loizaga, Saco Alarcón, 1973, n. 23, p. 400): "Quia si omnis unitas realis est numeralis, ergo omnis diversitas realis est numeralis. Sed consequens est falsum, quia omnis diversitas numeralis in quantum numeralis est aequalis, - et ita omnia essent aeque distincta; et tunc sequitur quod non plus posset intellectus a Socrate et Platone abstrahere aliquid commune, quam a Socrate et linea, et esset quodlibet universale purum figmentum intellectus." There is further evidence to support the claim that Duns Scotus should be added to the list of Auriol's targets here. Also, there are additional reasons to claim that even other thinkers should be included besides Burley and Scotus. For reasons of space, I cannot dwell on these points here. I limit myself to referring to what I have discussed in Fornasieri, 2019, pp. 70-91 and to the literature indicated therein. What stems from the aforementioned and is relevant to our purposes here is that, although Cross' thesis (which is quite intriguing) cannot be rejected with no recourse, there are good reasons to claim that the most profitable attitude here is probably to be cautious and acknowledge that a list of potential suspects (in the absence of decisive evidence) is the best we can get from Auriol's own words. 
individuals to which it said to belong either identice, that is, by asserting a real identity between that common nature and its subject, or non-identice, that is, by claiming that the common nature is not really identical with the supposita which instantiate it (i.e., the things that actually carry that common nature and thereby satisfy the intension of the term signifying that nature). Of course, a realist whose position may be somehow traced back to Auriol's description would take both options to be valid: as instantiations of the nature of humanity, both Socrates and Plato would be really the same as the humanity they instantiate and as being simultaneously instantiated by Socrates and Plato (and by every other human being alive at time t), the nature of humanity would necessarily remain something different from its own carriers. The problem, however, is that, for Auriol, none of them could in fact be accepted. If the first option were true (as realists somehow admit), then, say, Socrates would be to (his) humanity as one of the Divine Persons would be to the Divine essence, which is something we hardly understand by means of natural reason. Making this claim, in other words, would be like appealing to miracles to explain something (the possibility of essential predication and of scientific knowledge) of which we have experience in our everyday life and thereby should instead be described with the aid of solely natural reason. ${ }^{7}$ If, on the contrary, the second option were true, that is, if the common nature in Socrates were something distinct from Socrates himself, being something occurring identically in each individual of the human species as such (as some realists admit), then, by stating that Socrates is a human being (i.e., that Socrates is the bearer of the common nature of humanity) we would know nothing about Socrates. Socrates and his humanity, in fact, would be utterly distinct entities. ${ }^{8}$

${ }^{7}$ By presenting the theory of common nature the way he does, Auriol is undoubtedly tacitly giving his personal spin to it: while surely having been thought by those who endorse the view of such common nature as something really and entirely present in each individual of a given species, that common nature is clearly considered here by Auriol as something endowed with full, numerical existence, which is the conclusion that the great part of the authors he is supposedly referring to have strived to avoid. This remark, however, should not lead us to think of Auriol as a naïve thinker. On the contrary, Auriol proves he knows the realists' thesis of a less-than-numerical unity and he tries to show its inconsistencies as well. Since this paper is a sort of quick introduction to the text found in the appendix, this can only be done here by referring the readers to Auriol's discussion in the text below. On this point, see for example, n. 5.

${ }^{8}$ Petrus Aureoli, II Sententiarum, d. 9, q. 2, art. 1 (ed. Fornasieri, infra, p. 111: 17-28). 
In sum, as long as common nature is granted a form of autonomous subsistence, it will always be present in its entirety in each individual of a given species. According to Auriol, however, that would imply an undue multiplication of entities within the same substance, which would compromise its knowability: if one were to posit in Socrates the existence of humanity, as common nature, being fully inherent and still somehow distinct from Socrates himself, then, one would be inevitably committed to affirm that the reason by virtue of which Socrates is a human being is utterly different from the reason by virtue of which Socrates is Socrates. According to Auriol, then, the only way to avoid this counterintuitive conclusion is to get rid of realism and its heavy ontological tools.

In view of his harsh reaction to metaphysical realism, it is not hard to see why Auriol has earned, (somewhat hastily) over time, the title of a conceptualist thinker. I, however, argue that there are relevant elements to call him a moderate conceptualist. In fact, Auriol claims that, although no common natures are to be posited outside the mind, universals still have some ground in the extra-mental reality. As he states, it is the thing as it is in itself that makes the intellect form the concepts it forms about that thing. ${ }^{9}$ It is a sort of natural aptitude, with which extra-mental particulars are really endowed. Russ Friedman stresses this point quite efficaciously when he says: "for Auriol, there is a direct extra-mental ground for our universal concepts: there is, e.g., a characteristic innate to each and every member of the same genus that upon intellectual acquaintance leads us to form the concept of that genus." ${ }^{\prime 10}$ The remote metaphysical ground for universals is a set of individual quidditative properties each individual is naturally endowed with, which Auriol calls rationes. ${ }^{11}$ As he sees it, these features are what makes an object what it is: Socrates is Socrates, due to his ratio of substance, corporeality,

9 These are, in particular, the concepts of genus, species and difference. For Auriol discussing this point, see Petrus Aureoli, II Sententiarum, d. 9, q. 2, art. 1 (ed. Fornasieri, infra, p. 117: 3-14). For a discussion of Auriol's view on the matter, see Friedman, 1997, pp. 416-417.

${ }^{10}$ Friedman, 1997, p. 416.

${ }^{11}$ Auriol's treatment of the rationes is quite complex and still to be fully studied. It cannot therefore be entirely discussed here, nor is it the purpose of this paper. I will devote an entire chapter of the book on Auriol's theory of universals I am currently working on to this issue. For more on this, see, among others, Adriaenssen, 2014; Fornasieri, 2019; Friedman, 1997, 2000; Wöller, 2015. 
sensibility, rationality, which belong uniquely to Socrates. Despite their being different, each ratio coagulates into each other, giving birth to what he calls the individual's ultimate ratio, that is, its ratio atoma, Socrates' unique humanity. ${ }^{12}$ Also, Auriol claims that numerically distinct entities may have utterly similar (simillimae) rationes. For example, Plato's rationes are perfectly similar to those of Socrates. Plato has his own ratio of substance, corporeality, sensibility, rationality, his own unique humanity. Each and every ratio belonging to Plato, however, is fully indiscernible from each and every ratio belonging to Socrates and to any other human being. ${ }^{13}$ This is what makes them individuals of the same species, in the same way as Socrates and Brunellus can be conceived as individual of the same genus, as their rationes of substance, corporeality and sensibility are mutually indiscernible. For Auriol, then, although there are no universal features inhering in the extra-mental particulars, numerically distinct individuals may have, in fact, extremely similar aspects (rationes) according to which they can be legitimately conceived as entities of the same type. ${ }^{14}$ They do have some quidditative aspects able to guide our activity in concept formation. Upon this view, then, concepts are not merely mental constructs, they do not conventionally refer to things. Although they do not exist as universals in the extra-mental reality, what they are about (their content, so to speak) is fixed (through the rationes) in and by the extra-mental reality. In a nutshell, Auriol's conceptualism does not flow into a mere arbitrariness of the mind, as it is constrained or moderated by the nature of the outside objects.

One of the implications of Auriol's view on ontology, as it applies to the process of concept formation, is that although universals do not exist as such outside the mind, our concepts present things how they are. To put it as Auriol would, concepts are really identical to the extra-mental individuals

12 Petrus Aureoli, II Sententiarum, d. 9, q. 3, art. 1 (ed. Fornasieri, 2019, vol. II, p. 34). On this point, see Friedman, 2000.

${ }_{13}$ Petrus Aureoli, Scriptum I, d. 2, q. 1, art. 4 (ed. Buytaert, vol. II, p. 493): “[ ... quia $<$ Sortes et Plato $>$ addunt ad rationem substantiae rationem corporeitatis, et ad rationem corporis sensibilitatem, et ad rationem animalis rationabilitatem, et ad rationabilitatem autem penitus nihil addunt; idcirco, Sortes et Plato sunt penitus eiusdem rationis, quamvis realiter distinguantur."

14 Petrus Aureoli, II Sententiarum, d. 9, q. 3, art. 3 (ed. Fornasieri, 2019, vol. II, p. 54): "[...] nihil est in me quod sit in te. Et tamen nihil in me, cui simillimum non possit esse in te, ideo ego et tu non sumus idem; sed tamen ego possum esse talis, qualis es tu." 
they are about; they literally are the external objects they are about, insofar as they are cognized. According to him, being cognized for a thing means just being put into what he calls intentional or apparent being; cognizing is all about putting things in a different state, i.e., the state of appearing to the cognizer. As a result, since forming a concept, for Auriol, means just putting a thing in the state of being visible to whatever cognizes it, concepts are nothing but extra-mental particulars as they are made to appear to whatever cognizes them. What marks the difference between them is appearing, so that every time we conceive of a thing, nothing ensues but the cognized thing as it appears to the cognizer. ${ }^{15}$ Of course, it is Auriol's conviction that this claim also applies to the formation of universal concepts. As he sees it, that we may have universal concepts is something no one could ever disclaim. ${ }^{16}$ In this framework, then, the concept of Socrates as a human being, i.e., the universal concept of human being, is Socrates as put into apparent being and thereby appearing to the cognizer, according to the ratio of humanity Socrates is really endowed with. As one may recall, one of Auriol's main tenets about ontology is that rationes of the same type, while belonging to fully distinct particulars, are nonetheless mutually indiscernible and thereby serve as the metaphysical basis for our concepts about them. The result is that the concept of human being is all human beings, not as they exist in the extra-mental reality, but as they appear to the cognizer, through the ratio of humanity we grasp in Socrates, and still occurs as maximally similar in every other human being. ${ }^{17}$

15 Petrus Aureoli, Scriptum I, d. 27, q. 2, art. 2 (ed. Friedman, Nielsen, Schabel, 2020, p. 10: 365-366). See also, Petrus Aureoli, Scriptum I, d. 9, pars 1, art. 1 (ed. Friedman, Nielsen, Schabel, 2020, p. 8: 339-341).

16 See Friedman, 2013, p. 582.

17 Petrus Aureoli, Scriptum I, d. 27, q. 2, art. 2 (ed. Friedman, Nielsen, Schabel, 2020, p. 15: 520-525): "Relinquitur ergo ut detur septimum, scilicet quod (conceptus) sint verae rosae particulares et flores, non quidem ut existunt exterius, sed ut intentionaliter et obiective, et secundum esse formatum concurrunt in unum quid simpliciter, quod est praesens in intellectu per speciem intelligibilem vel per actum. Et cum constet quod tale quid non est in animo nisi dum actu intelligit, species autem intelligibiles remanent sine actu, manifeste concluditur quod talis res in esse huiusmodi non emanat nisi dum actu intelligitur et in intellectione sive notitia actuali." See also note 12 and Petrus Aureoli, Scriptum I, d. 27, q. 2, art. 2 (ed. Friedman, Nielsen, Schabel, 2020, p. 13: 464-468): "[...] in phantasmate; aut actus intellectus; aut res aliqua accidentalis existens subiective in intellectu ad quam intellectio terminetur; aut rosa quaedam vel flos subsistens sicut 
Despite the anti-realist attitude of Auriol's philosophy, universals, for him, do grasp things the way they are, as concepts are (to some extent) the things they are about. They are the "sum" of a given individual plus its property of being cognized, i.e., its property of being in relation with and thereby appearing to the mind. According to Auriol, an object cognized can never be really distinct from its being cognized: the concept of, say, human being is Socrates as indistinguishably mixed together with passive conception (conceptio passiva), i.e., with its being a concept conceived by the mind. ${ }^{18}$ Upon this framework, a concept and the object of which it is a concept are numerically the same entity. ${ }^{19}$

\section{Auriol's Theory of Essential Predication}

According to Auriol's ontology and his theory of concept formation, our general terms do not immediately signify a universal property really occurring in each individual of a given species or genus. They signify the objects they are drawn from, insofar as they signify the concepts, which Auriol has in

posuit Plato; aut rosae particulares existentes extra; aut rosae illae particulares secundum aliud esse, intentionale videlicet et formatum, existentes in anima obiective." Although it is impossible to go deeper into this issue here and now, as it is not the purpose of this paper, it is worth noting that, given Auriol's account of the rationes, the cognizer would need in theory just one particular to form the relevant universal concept. A more in-depth discussion of this issue will be found in the book on Auriol's theory of universals I am currently working on. Good treatments of the same problem are to be found in Friedman, 1997, 2000.

18 Petrus Aureoli, Scriptum I, d. 23, art. 2 (ed. De Rijk, 2005, pp. 718-719); Petrus Aureoli, Scriptum I, d. 27, pars 2, art. 2 (ed. Friedman, Nielsen, Schabel, 2020, p. 18: 643-648): “[...] res posita in esse formato non est aliquid aliud quam res extra sub alio modo essendi [...] vera res habet esse fictitium et apparens. Nec propter hoc fit bis, sed idem fit in duplici esse: realiter quidem exterius in natura, intentionaliter vero in mente." Petrus Aureoli, II Sententiarum, d. 3, q. 2, art. 4 in Firenze, BNC, conv. soppr., ms. A.3.120, f. 27rb; Padova Biblioteca Antoniana, ms. 161 scaff. IX, f. 24rb: "Sic igitur est eadem res addita alia et alia apparentia, quae nihil est reale, sed tantum intentionalenon enim apparentia illa est in re, sed in intellectu tantum, tunc igitur venit difficultas, quomodo illud additum se habebit ad rem, puta apparentia, qua res apparet clare, et illa qua apparet obscure, aut ut ad substratum, aut ut ad compositum."

19 This is not the place to dwell on Auriol's view on intellectual cognition. For more on the mechanics of Auriol's theory of concepts, see Fornasieri, 2021; Friedman, 2015. 
turn made invisible by identifying them with the objects cognized.$^{20}$ In this case, "human being" signifies the really existent individual human being called Socrates plus Socrates's being cognized. It signifies Socrates as placed into apparent being.

However, a potential objection arises against this view, according to which some sort of formalities have to be admitted in re, if we really want to make sense of essential predication. Auriol deals with it in distinction 9, question 2, article 1 of his Commentary on Book II of the Sentences. Taking the stand of his imaginary realist opponent, Auriol argues that 'Socrates is a human being' can never be equated to a predication (i) of a mental token of a real entity (i.e., Socrates as a real being and human being as a concept); (ii) of a thing of itself (i.e., Socrates of himself); (iii) of two really distinct entities (i.e., Socrates and humanity as really distinct items). None of them could actually work: if (i) were the case, then, provided that Socrates as a real being is [s] and human being as a concept is $[\mathrm{H}]$, stating $H s$ would amount to saying that Socrates is a concept, which is clearly false; if (ii) were the case, then, stating that Socrates is a human being would be the same as stating that Socrates is Socrates, which would reduce essential predication to a mere tautology, deprived of any increasing of informational content about the object; finally, if (iii) were the case, then, asserting that Socrates is a human being would be like stating that this individual being called Socrates is this individual being called Plato, given that Socrates and humanity are two really distinct items. As a consequence, the opponent concludes the only way we have to give a compelling description of how the subject and its predicate relate in essential predication is by claiming that general terms like "human being" signify some kind of formalities, which occur in Socrates, independently of any cognitive act. ${ }^{21}$

Quite surprisingly, Auriol seems unconcerned about a valid argument which is directly aimed against his moderate conceptualism. Auriol's idea is that such conclusion is far from being necessary. More specifically, he claims that a statement like that would follow only upon admitting a dangerous misunderstanding of the mechanics of intellectual cognition. Not by chance, Auriol's solution aims precisely at showing how intellectual cognition relates

${ }^{20}$ Friedman, 2013, p. 584.

${ }^{21}$ Petrus Aureoli, II Sententiarum, d. 9, q. 2, art. 1 (ed. Fornasieri, infra, p. 113: 1-12). 
to essential predication, that is, at how essential predication can be described as a predication of the type (ii).

Auriol's solution can be boiled down to three main theses: (a), (b) and $(\mathrm{c}):^{22}$

(a): Essential predication is a predication of the type (ii).

(b): Essential predication, as a predication of the type (ii), implies that the subject and the predicate of a predicative statement are concepts.

(c): Essential predication, as a predication of the type (ii), can neither be reduced to tautology, nor to a predication of the type (i), provided that concept formation does not add a separable (although accidental) feature to what is being conceived through the relevant cognitive act.

According to Auriol, (c) proves as a condition for (a), as it proves as a condition for (b), which, in turn, proves as a condition for (a). To put it in a formula: (a) iff (b); (b) iff (c); (a) iff (c).

Auriol's thesis (a) claims that $F x$ is the same as $F=x$, which means that when we state that Socrates is a human being, the semantic values of the terms "Socrates" and "human being" are nothing but the same individual Socrates. According to Auriol, this is possible because each individual thing is endowed with the natural ability to make the intellect form several concepts of itself, to the point that really distinct particulars may be indeed conceived as tokens of the same type. Insofar as Socrates is apt to make a more and a less determined concept of himself, we can form the concept of Socrates, that of a human being or that of animal (among others). However, since upon Auriol's view concepts are identical to the object they are about, it occurs that the concept of Socrates, that of a human being and that of animal actually refer to the very same existing Socrates. As Auriol claims, they are Socrates, though conceived in two different ways. ${ }^{23}$

The result is that when we state that Socrates is a human being or an animal, or even when we state that a human being is an animal (while referring to Socrates), we are just making an identity statement about Socrates; we are just repeating him. Essential predication is a predication of the type (ii), but with significant qualifications. More precisely, essential predication amounts to predicating a thing of itself, while being presented according

22 This treatment partly refers to what I have discussed in Fornasieri, 2021.

${ }^{23}$ On these points and on Auriol's defense of his view, see the first section. 
to different conceptions. ${ }^{24}$ Christian Rode makes this point in a very sharp manner saying that: "[i]n this correct sense, a predication amounts to the following operation: an individual thing which I conceive in a determinate manner is the same thing which I conceive in a confused way. The underlying thing in the extra-mental reality is the same, but the modes of presentation [...] are different. We have one thing, but two different esse apparentia." ${ }^{25}$

As one can immediately recognize, in order to explain (a), one is thereby compelled to appeal to Auriol's thesis (b). In fact, this is precisely Auriol's point.

His first remark is certainly trivial, but also surprisingly robust: without an entity being cognized, which is to say, without what he has called conceptio passiva, making a statement about the entity's nature could never be possible. As a mental act, essential predication requires that both the subject and the predicate, which make up the predicative statement, be concepts.

This evidence, however, gains even much more importance in Auriol's framework, as it underpins his theory of essential predication as a predication of the type (ii) and thereby (quite significantly) his conceptualism. This can easily be shown by quickly comparing Auriol's view with the one held by his realist opponents here. According to their view, the semantic value of the term "human being" can never be reduced to a certain conception of Socrates. Since we can predicate the term "human being" of Socrates and no mental being can ever be predicated of a real being, there has to be admitted some kind of distinction in Socrates himself between Socrates and his humanity. The difference between the subject and the predicate of a predicative statement has to occur independently of any cognitive activity. Now, if no common natures or universal exist in the extra-mental reality as properties instantiated in the relevant particulars and only particulars are to be posited outside the mind (as Auriol claims), it is impossible for a thing to be predicated of itself (thesis (a)) unless it is conceived (thesis (b)). Upon Auriol's conceptualism, the diversity between the subject and the predicate cannot be thought of as a difference involving a distinction in the extra-mental

${ }^{24}$ See, n. 9: Petrus Aureoli, II Sententiarum, d. 9, q. 2, art. 1 (ed. Fornasieri, infra, p. 117: 3-14).

${ }^{25}$ Rode, 2017, p. 150. 
reality. As a result, it can only arise at a conceptual level, which means that, for Auriol, essential predication essentially involves only concepts. ${ }^{26}$

These remarks immediately bring us to Auriol's thesis (c). In fact, one might ask how Auriol's theory of essential predication can account for the diversity between the subject and the predicate without either being reduced to a mere tautology, or collapsing into a predication of the type (i). In a nutshell, if essential predication is nothing but a kind of selfpredication, how can Auriol account for the diversity between the subject and the predicate of a predicative statement? Furthermore, if the diversity between the subject and the predicate should not be thought of as a difference involving a distinction in the extra-mental reality, but as a difference arising at a conceptual level, how would we not be compelled to claim that concepts are predicated of real beings?

As to the first question, Auriol agrees that, whether essential or not, predication requires some manner of diversity between subject and predicate. Stating $F x$ adds some information to (our knowledge of) $x$. Essential predication, in other words, must always come with the increase of our informational content about the object about which that predicative statement is made. That is what marks the difference with tautology. In contrast with realism, however, Auriol's idea is that such diversity between a subject and a predicate is perfectly accounted for by the interaction between a thing and the mind. ${ }^{27}$ Conceiving of Socrates as a human being or an animal is sufficient to increase our knowledge of him, as it appears to us according to different essential aspects (rationes) he is endowed with. According to Auriol, each individual thing has the natural ability to make the intellect form several concepts of itself, to the point that really distinct particulars may be indeed conceived as tokens of the same type. As a result, no formalities or universals to which our general terms correspond are to be posited in the extra-mental reality.

The second question represents a much more threatening problem for Auriol's theory of essential predication. According to (a) and (b), essential predication as a predication of the type (ii) involves concepts formation. It would therefore seem to be implied that, when we predicate human being or animal of Socrates, we are saying that Socrates is a human being, in

${ }^{26}$ Petrus Aureoli, II Sententiarum, d. 9, q. 2, art. 1 (ed. Fornasieri, infra, p. 117: 17-29).

27 On this point, see Friedman, 1999. 
fact. Auriol's way out is that essential predication can be taken in a twofold sense. On the one hand, being predicated can be taken according to what it directly means. When we say that Socrates is a human being, "human being" can be taken to directly signify Socrates's being cognized, his being a mental concept in the mind. Now, if we were to take essential predication in this way, Auriol acknowledges, we would end up claiming that an existing entity such as Socrates is the same as one endowed with diminished or intentional existence, which is clearly false. Essential predication could never occur and the realists' criticism would also be fair. At any rate, Auriol continues, there is at least another available option. Being predicated, in fact, can be taken somehow indirectly. When we say that Socrates is a human being, Auriol continues, "human being" can also be taken to signify Socrates's being cognized, his being a mental entity only as being a feature necessarily included within what the predicate "human being" actually means. Every time "human being" is attributed to Socrates by virtue of a cognitive act, its being mind-dependent (i.e., a concept) may be thought of as something involved in what "human being" directly signifies. ${ }^{28}$

However, a further question arises at this point: if claiming that through predication being a mental entity is necessarily included within what human being signifies, would it not therefore imply that an accidental feature is added to what Socrates is? Would we still be able to talk of essential predication in general? After all, Socrates is a human being whether we conceive of him as such or not.

Auriol's answer to the question seemingly lies on (albeit without discussing it) the distinction between accidental, separable properties and accidental, non-separable properties. ${ }^{29} \mathrm{His}$ idea is that essential predication is maintained and thereby (c) (i.e., the thesis that (a) and (b) are valid) is verified, because passive conception, i.e., the property of being cognized a thing acquires as soon as it is cognized, does not add a separable, however much accidental, feature to what is being conceived through a cognitive act.

As Auriol remarks, it is impossible even to think of concepts and essential predication without also thinking of their being cognized by a mind's act. Cognizing a thing always entails that thing's being cognized. Since essential predication involves the mind's activity (as thesis (b) shows), then,

${ }_{28}$ Petrus Aureoli, II Sententiarum, d. 9, q. 2, art. 1 (ed. Fornasieri, infra, p. 117: 15-29).

29 The primary source for this distinction is: Porphyry, Isagoge, c. III. 
the property of being cognized a thing acquires by being cognized is part and parcel of that concept, as it is employed to compose a predicative statement. They are inseparable features. ${ }^{30}$ Neither concepts nor essential predication could ever be possible without something's being cognized. What follows is that, far from impeding essential predication, the passive conception is necessary to it. It is a feature intrinsically included in each concept we employ whenever we state $F x \cdot{ }^{31}$ It is necessarily included in that which is conceived and thereby no accidental, separable property of a concept.

Notably, this coincides with Auriol's claim that a concept is the real referent it is referred to, as indistinguishably mixed together with passive conception (conceptio passiva). ${ }^{32}$ By conceiving an extra-mental particular, the passive conception cannot be separated from what is conceived through a concept. They do not entail composition, nor do they differ numerically. They are not two really distinct items. Auriol makes this point clearer by stating that the passive conception does not regard the object it is associated with as a substratum. Passive conception is not superimposed to the content of what is conceived. As previously mentioned, our concepts, for Auriol, are nothing but the really existent particulars plus their being conceived and made apparent to the cognizer. ${ }^{33}$

30 Petrus Aureoli, II Sententiarum, d. 9, q. 2, art. 1 (ed. Fornasieri, infra, p. 117: 17-29).

${ }^{31}$ Rode, 2017, p. 151: "[i]f the intellect conceives the extra-mental thing in a concept, it cannot separate the passive conception from the quiddity. If we prescinded from the passive conception completely, we would not be able to form an essential predication in the first place [...]. Hence the passive conception cannot impede the essential predication, because if we abstracted from it, the predication would not be possible. Auriol makes very clear: we cannot conceive a thing without its being conceived, without the passive conception. If we tried, we would contradict ourselves: we would try to intellectually grasp a thing without grasping it conceptually."

32 See n. 1.

33 Petrus Aureoli, Scriptum I, d. 23, art. 2 (ed. De Rijk, 2005, pp. 718-719): “Et propter hoc obiectiva conceptio passive dicta non respicit rem per modum substrati, ymo res que concipitur est aliquid sui et immiscetur indistinguibiliter sibi, unde conceptio rose idem est quod rosa, et conceptus animalis idem quod animal. Iste nimirum conceptus claudit indistinguibiliter realitates omnium particularium animalium et quendam modum essendi qui est intentionalis, qui non est aliud quam passiva conceptio." For a more detailed account of Auriol's view of his theory of predication, see Friedman, 1999, 2000. 


\section{Connotation: The Background of Auriol's Theory of Essential Predication}

Once the backbone of Auriol's theory of essential predication has been given, however, one is left with an aspect that needs to be investigated. In fact, one might question how it can be the case that something necessarily involved in each predicative statement about a certain thing (i.e., passive conception) is not directly predicated of that thing. In other words, how it can be the case that Socrates's being cognized does not end up being predicated directly of Socrates, being necessarily involved in our predicating, say, "human being" of Socrates himself. ${ }^{34}$ To answer this question and thereby make sense of (c) - and thus of (a) and (b) - Auriol employs the noetic tool of connotation. His view on connotation as applied to intellectual cognition, concept formation and essential predication is barely discussed in his II Sententiarum, distinction 9, question 2, article 1. Although, it is mostly taken for granted, as it occurs as a sort of nuanced theoretical background to his discussion, his thinking on the matter can be easily (and safely) reconstrued by reading his claims against those texts where he openly addresses the issue. In his view, connotation provides the most effective and elegant way to describe how something's being cognized, i.e., its conceptio passiva, is necessarily required and indirectly predicated within every predicative statement.

Auriol is convinced that his theory of essential predication is not affected by the inconsistency mentioned above, because passive conception occurs as a co-signification of what a concept directly means. It is something implicitly connoted by concepts' primary signification. In Auriol's view, connotative terms have a primary and a secondary meaning, which are in fact mutually related. Connotative terms, in other words, are terms you cannot even think of without also thinking (quasi cointellecta) ${ }^{35}$ of what they indirectly refer to as their secondary meaning. While expressing their primary signification, they simultaneously co-signify to what that signification is necessarily linked. One of Auriol's most famous examples concerns the term "flesh": while "flesh" directly (in recto) signifies a given flesh, it

34 See Auriol's claim at n. 27.

35 Petrus Aureoli, Scriptum I, d. 45, art. 1, ed. Romae 1596, f. 1067D-Fb. 
also indirectly and simultaneously (in obliquo) co-signifies the animal to which that flesh belongs. ${ }^{36}$

Now, his fundamental idea is that our concepts cannot but be thought of as connotative notions. Auriol argues, as being extra-mental particulars endowed with the esse apparens, namely, as particulars just being made to appear to whatever cognizes them, our concepts cannot even be thought of without also referring to their relevant cognitive acts. A thing's being cognized, i.e., its being a concept of the mind, is always obliquely cosignified whenever the content of that concept is thought of ${ }^{37}$ The result is that what is directly predicated of Socrates when it is stated that Socrates is a human being is nothing but the primary meaning of those concepts. The very same particular is conceived through different concepts. However, the ways that thing is differently conceived by (i.e., the different passive conceptions) do not actually fall into the predication, due to Auriol's claim that they are only obliquely co-signified, connoted within each concept's primary meaning. As Christian Rode remarks very clearly, Auriol may validly assert that a human being is an animal, "because the passive conception is not predicated directly (in recto), but indirectly or implicitly (in obliquo)." 38

Now, according to Auriol, the conceptio passiva, that is, our concepts' being sets of objects as cognized, is not an accidental feature of our concepts. Concepts are extra-mental particulars plus their being cognized. How

36 Petrus Aureoli, Scriptum I, d. 8, q. 3, art. 2, (ed. Friedman, Nielsen, Schabel in The Electronic Scriptum, p. 14: 5-11): "Est enim considerandum quod sunt aliqua quae nihil dicunt nisi in recto, utpote homo, leo, et ceterae substantiae; et sunt aliqua quae, cum hoc quod dicunt aliquid in recto, aliqua significant in obliquo, ut simitas dicit concavitatem in recto et nasum in obliquo, et similiter caro dicit substantiam propriam in recto et animal in obliquo, quia dicitur caro alicuius caro; similiter etiam os, manus et similia connotant aliquid in obliquo, principale autem significatum est illud quod dicunt in recto."

37 Petrus Aureoli, II Sententiarum, d. 3, q. 2, art. 4, in ms. Firenze, 3.120, f. 27rb: "Tunc ad aliud quando dicitur quod non praedicatur res de re, sed cum ratione. Respondeo, aut praedicatio intelligitur fieri ratione ipsius concipi, vel ratione rei indivisae tamen a concipi. Primo modo propositio est falsa, quia esset sensus, cum dico: 'homo est anima', conceptus hominis est conceptus animalis, quod falsum. Secundo ergo modo tantum tenet praedicatio, et sic verificatur propositio, cum dico 'homo est animal', non ratione concipi in recto, sed in obliquo per explicationem, sicut dicit Avicenna." Italics are mine. Compare this text with Petrus Aureoli, II Sententiarum, d. 9, q. 2, art. 1 (ed. Fornasieri, infra, p. 117: 17-29).

38 Rode, 2017, p. 150. 
does connotation help to solve the question raised at the end of the previous section, then? In other words, does Auriol imply that passive conception is necessarily included in, say, the definition of the concept of human being? Is it really the case that stating that human being is a concept equals to stating that Socrates is a concept? After all, as Fabrizio Amerini rightly notes, doubts like these were the core of the objections raised by Hervaeus against Henry of Ghent's theory of intentions, which is very close to Auriol's on this specific point. ${ }^{39}$ Auriol's idea, in fact, is that the propositions "human being is a concept" and "human being is a rational animal" are indeed the same. They are both per se primo modo propositions. ${ }^{40}$ Upon this view, then, there seems to be little chance for Auriol's theory of essential predication to avoid Hervaeus's criticism. It seems committed to the quite absurd conclusion that: "[i]f "man is universal" were a per se predication, the property of "being universal' would be part of the essence of man."

Regardless of the apparent validity of such conclusion, Auriol maintains that it could never apply to his case. As far as he sees it, connotation suffices to avoid it. Although he maintains that "human being is a concept" equals to "human being is a rational animal", he believes that properties like "being a concept" or "being cognized" are not part and parcel of human being's essential definition. General concepts are extra-mental particulars plus their own being cognized. Their being cognized (their passive conception), however, is just implicitly included in what each concept primarily means, upon Auriol's analysis. The fact that human being is a concept is only connotatively (laterally or co-incidentally, so to speak) included in human

39 Hervaeus Natalis, Tractatus de secundis intentionibus, d. 3, q. 3 (ed. J. P. Doyle, 2008, p. 434). On this point, see Amerini, 2009; 2017.

${ }^{40}$ Petrus Aureoli, Scriptum I, d. 23, art. 2 (ed. De Rijk, 2005, p. 719): “Dicendum quidem ad hoc quod idem est iudicium de prima intentione et de vera re. Unde si ista est per se primo modo 'Animal est vera res', et ista 'Animal est prima intentio'; in utraque namque predicatur ens: in prima ens reale, in secunda ens intentionale. Cum igitur animal, inquantum differt ab homine ratione, non sit precise res, ymo includens aliquid rationis, nec sit precise ratio, ymo includens aliquid vere realitatis, nec sit compositum ex realitate et ratione tamquam ex duobus que distinguibilia sint, sed sit aliquid simplicissime et indistinguibiliter adunatum,- - tam 'vera res' quam 'prima intentio' predicari possunt per se de ipso, quia non se habent per modum partis. Et predicantur in primo modo, sicut et 'ens'; nec ponuntur in diffinitione animalis, sicut nec ipsum ens." For a discussion of Auriol's view on perseitas, see Friedman, 2013, pp. 529-594.

${ }^{41}$ Amerini, 2017, pp. 135-136. 
being's "being a rational animal". To put it differently, Auriol claims that being a concept is not part of human being's essential definition, because it is not primarily, but only secondarily involved in what human being directly signifies. Being a concept is just a co-signified feature of each and every concept and that suffices, in Auriol's view, to avoid Hervaeus's criticism. ${ }^{42}$ Connotation, in sum, provides Auriol the tool to describe how our concepts can be really about extra-mental things, without postulating common natures or universal properties instantiated by several individuals at once to which our concepts should correspond:

1. Only particulars exist in the extra-mental reality.

2. Each particular is naturally apt to make the mind form more concepts of itself.

3. Our (general) concepts are particulars being cognized.

4. They are particulars in recto and concepts only in obliquo.

5. Essential predication is valid upon this view, because the predicate's being a concept is only obliquely predicated of the relevant subject term.

According to Auriol, every existing thing, insofar as it exists, is singular. Given that human being does not exist outside the mind, but it is a concept, then human being cannot be thought of without immediately referring to the cognitive act by which it is formed. At the same time, being just co-signified by what human being primarily means, being cognized does not alter what human being primarily means. As soon as it is drawn from Socrates, the concept of human being directly means Socrates, while it signifies Socrates's being cognized only in an oblique manner. What stems from this view and proves relevant to our purposes is that, in Auriol's account, connotation serves as a decisive support for the kind of moderate conceptualism he endorses in his Commentary on Book II of the Sentences, distinction 9, question 2, article 1 . His theory of essential predication, in fact, is entirely built upon his ontology of singulars. He takes it to be as an answer to the inconsistencies that realists would meet, given their own premises. In other words, proving that his claims on essential predication is valid means for Auriol to prove that realists are wrong on their own assumptions. Now, the fact is that, upon Auriol's own admission, connotation serves precisely this purpose. It is the tool which makes sense of his theory of essential

${ }^{42}$ Fornasieri, 2021, pp. 44-45. 
predication and thereby of his own moderate conceptualism. It is connotation that explains how essential predication works, without endorsing realism. By doing it, connotation implicitly serves as a justification for Auriol's moderate conceptualism.

\section{Conclusion}

Auriol's use of connotation is deeply intertwined with both his ontology and his epistemology. It is the meeting point between them. Once Auriol has rejected realism, in fact, predication becomes just a matter of concepts. No universals in re, no common natures really instantiated in the individuals of a given set are signified by our general terms. As a consequence, Auriol needs to find a compelling way to explain how essential predication occurs - a way which agrees with his lean ontology. Now, according to him, connotation serves precisely this purpose: it manages to explain how mental items can be predicated of a real particular, without entailing contradiction. Being connotative notions, in fact, concepts qua concepts are spoken of a certain individual only in obliquo. What is in recto predicated of that thing is just what those concepts directly mean, which is nothing but that very same thing under different conceptions. Essential predication is therefore granted. Thanks to the noetic tool of connotation, the test has been passed and Auriol's moderate conceptualism is safe. 


\section{Appendix}

\section{Manuscript Tradition}

Auriol's Commentary on Book II of the Sentences is handed down (either partially, or integrally) by eighteen manuscripts: ${ }^{43}$

A. Assisi, Biblioteca del Convento di S. Francesco, ms. 197

B. Barcelona, Archivo de la Corona de Aragón, ms. Ripoll 77bis

D. Düsseldorf, Landes und Staatsbibliothek, ms. B. 159

Fb. Firenze, Biblioteca nazionale centrale, ms. conv. soppr. A.3.120

Fc. Firenze, Biblioteca nazionale centrale, ms. conv. soppr. B.6.121

N. Napoli, Biblioteca nazionale, ms. VII.C.3

O. Oxford, Balliol College, ms. 63

Pb. Paris, Bibliothèque nationale de France, ms. latin 3066

Pc. Paris, Bibliothèque nationale de France, ms. latin 15867

Pg. Padova, Biblioteca Antoniana, ms. 161 scaff. ix

Pi. Padova, Biblioteca Universitaria, ms. 1580

Pj. Pelplin, Biblioteka Seminarium duchownego, ms. 46/85

Vg. Vaticano (Città del), Biblioteca Apostolica, ms. Borg. lat. 404

Vi. Vaticano (Città del), Biblioteca Apostolica, ms. Vat. lat. 942

Vl. Vaticano (Città del), Biblioteca Apostolica, ms. Vat. lat. 943

Vm. Vaticano (Città del), Biblioteca Apostolica, ms. Vat, lat. 94444

Vn. Vaticano (Città del), Biblioteca Apostolica, ms. Vat. lat. $946^{45}$

VQ. Vaticano (Città del), Biblioteca Apostolica, ms. Vat. lat. 6768

Auriol's Commentary on Book II of the Sentences, distinction 9, question 2, article 1 is preserved in the following manuscripts: D (ff. 56ra-58va); Fb (ff. 38vb-40ra); Fc (ff. 39va-40vb); N (ff. 137rb-138rb); Pb; ${ }^{46}$ Pc (ff. 43vb-45va); Pg (ff. 34va-35vb); Pj (ff. 150rb-151vb); Vg (ff. 29va-30va); Vi (ff. 30rb-31rb).

D: Parchment; late fifteenth century; $270 \times 200 \mathrm{~mm}$; two columns; ff. 1r-178v: Petrus Aureoli: Commentary on Book II, labeled as Quaestiones theologicae XLV; ff. 179r-192v: Petrus Aureoli, De conceptione B.V.M.; ff. 192v-203v:

\footnotetext{
43 The initials for each manuscript are taken from Schabel, 2000.

44 This manuscript is lacking from the list found on the Peter Auriol Homepage.

45 This manuscript is lacking from the list found on the Peter Auriol Homepage.

46 Unfortunately, I could not have access to $\mathbf{P b}$. This should not be much of a problem, however, because, as Schabel points out, $\mathbf{P b}$ carries a text which is even worse than $\mathbf{X}$.
} 
Petrus Aureoli, Repercussorium editum contra adversarium innocentiae matris Dei, f. 204r-205v. ${ }^{47}$

Fb: Parchment, fourteenth century; $325 \times 225 \mathrm{~mm}$, two columns; ff. 1r-124r: Petrus Aureoli, Commentary on Book II.

Fc: Parchment; fourteenth century; $320 \times 240 \mathrm{~mm}$; two columns; ff. 1-121r: Petrus Aureoli: Commentary on Book II; 121r -121v: Auriol's Commentary on Book II tabula quaestionum; 123r-146v: Petrus Aureoli: Commentary on Book III.

N: Parchment; fourteenth century; $238 \times 335 \mathrm{~mm}$; two columns; ff. 1r-110r: Anonymus (maybe Conradus de Soltau); ff. 111r-199r: Petrus Aureoli, Commentary on Book II; ff. 199v-200r: scattered notes; ff. 200v-201r: sermon for a degree in law; f. 202rv: Auriol's Commentary on Book II tabula quaestionum. ${ }^{48}$ Pg: Parchment; fourteenth century; $310 \times 210 \mathrm{~mm}$; two columns; ff. 1r-110v: Petrus Aureoli, Commentary on Book II.

Pb: Parchment; fourteenth century; $325 \times 210 \mathrm{~mm}$; two columns; ff. 1r-116v: Petrus Aureoli, Commentary on Book II.

Pc: Parchment; fourteenth century; $310 \times 210 \mathrm{~mm}$; two columns; ff. 1r-140v: Petrus Aureoli, Commentary on Book II; ff. 141r-208r: Petrus Aureoli, Quodlibet. Pj: Parchment; fourteenth century; $321 \times 218 \mathrm{~mm}$; two columns; ff. 3r-113v: Petrus Aureoli, Commentary on Book IV; ff. 114r-240v: Petrus Aureoli, Commentary on Book II; ff. 241r-248v: Petrus Aureoli, Commentary on Book III.

Vg: Parchment; fourteenth century; $225 \times 325 \mathrm{~mm}$; two columns; ff. 1r-82r: Petrus Aureoli, Commentary on Book II.

Vi: Parchment; fourteenth century; $370 \times 250 \mathrm{~mm}$; two columns; ff. 1r-95v: Petrus Aureoli, Commentary on Book II.

In contrast, $\mathbf{A} ; \mathbf{B} ; \mathbf{V l} \mathbf{V} \mathbf{V m} ; \mathbf{V n} ; \mathbf{V Q}$ pass down either an abbreviated version of Auriol's Commentary on Book II $(\mathbf{O} ; \mathbf{V m} ; \mathbf{V n})$, or a list of question from Auriol's Commentary on Book II (A; B; Vl; VQ).

$\mathbf{P i}$ is a different story altogether. It is a composite manuscript, that gathers together scattered questions from the works of Antonius Andrea, William Alnwick, Peter Auriol, James of Viterbo, Duns Scotus and maybe (the attribution is uncertain) Thomas of Cataloña. ${ }^{49}$ However, as Doucet ${ }^{50}$ rightly shows, out of the 22 questions that the manuscript hands down as Auriol's questions on

\footnotetext{
47 See also Mazurek, Ott, 2011.

48 See also Cenci, 1978, p. 398.

49 For the manuscript description, see Marangon, 1997, pp. 229-230.

${ }^{50}$ Doucet, 1936, pp. 415-416.
} 
Metaphysics, only nine are openly found in Auriol's Commentary on Book II, namely, questions $11-15$ and $17-20 .{ }^{51}$ The remainder, although it is found among questions which are clearly from Auriol, is still to be ascribed to him. ${ }^{52}$

\section{Ratio Edendi}

This semi-critical edition of Auriol's distinction 9, question 2, article 1 presented here should be taken as introductory. Following the hypothesis on the family tradition formulated by Chris Schabel,,$^{53}$ eight manuscripts have been singled out, because of the date of composition and the quality of the text. ${ }^{54}$ These are: $\mathbf{F b} ; \mathbf{F c} ; \mathbf{N} ; \mathbf{P g} ; \mathbf{P c} ; \mathbf{P j} ; \mathbf{V g} ; \mathbf{V i}$. As Schabel argues, there is no sign of a clear stemma. ${ }^{55}$ Still, I agree with Schabel that $\mathbf{F b}$ and $\mathbf{P g}$, due to their quality, can be considered as exemplars of the two families, which preserve Auriol's Commentary on Book II. As Schabel puts it:

On slim evidence one can group FbPbPcPiPj against DFcNPgVgViX $[\ldots] \mathrm{Fb}$ has few enough errors that it could be the exemplar from which stem all other witnesses [...] No subgroups emerge. Ranking the groups from best to worst: $\mathrm{PgDViFcNVgX}$ [scil. the printed edition], $\mathrm{X}$ having many significant minor variants; and $\mathrm{FbPjPiPcPb}, \mathrm{Pb}$ being quite a bit worse. Overall ranking: FbPjPgPiPcDViNFcVgXPb. ${ }^{56}$

In general, all the manuscripts offer a better text than the one offered by the printed edition of 1605 (labelled as X in the edition), which is, in contrast, poor and unreliable. Besides providing significant corrections to some grammatical inconsistencies, they have been fundamental to make Auriol's thought clear and accessible to readers. I have chosen to follow $\mathrm{Fb}$ as the leading manuscript for this edition. It has been integrated especially with the often helpful reading of Pg, $\mathrm{Pj}$ and $\mathrm{Pc}$, whenever $\mathrm{Fb}$ is grammatically incorrect, corrupted or inconsistent. Note, however, that they basically overlap. In the few cases where $\mathrm{Fb}$ and the other manuscripts have different, but paleographically similar and semantically

51 Note that question 15 in Pi (ff. 221va-222vb) corresponds to Auriol's II Sententiarum, d. 9, q. 3, art. 2; a text which is strictly connected to the text edited here.

${ }_{52}$ I am currently working on this manuscript, trying to see whether q. 7 and q. 9 are in fact attributable to Auriol.

53 Schabel, 2000, pp. 155-157.

${ }^{54}$ Note that $\mathbf{D}$ is a fifteenth century manuscript, while $\mathbf{P b}$, as Schabel points out, has a worse quality than the printed edition $\mathbf{X}$.

55 Schabel, 2000, pp. 155-157.

${ }_{56}$ Schabel, 2000, pp. 155-156. 
substitutable words, I occasionally opt for a reconstruction according to the sense. The main criterion I have followed to build up this text is to offer the reader a reliable and easily understandable version of one of the most significant discussions Auriol makes about his view on how ontology and epistemology are intertwined. By following the editorial rules supplied by Lauge Nielsen and Cecilia Trifogli, and Luigi Campi, ${ }^{57}$ I have thus identified four types of variants: inversions, omissions, additions and substitutions. With the exception of the inversions, all the variants of all the eight manuscripts have been included in the apparatus. In order to provide an overall evaluation of the manuscripts, however, variants have been distinguished from scribal errors throughout the manuscripts' analysis. Given the lack of a clear stemma, ${ }^{58}$ an error is considered here as a clearly wrong reading. The most frequent cases are grammatical mistakes, omissions which make the meaning of a given passage opaque or unintelligible and the use of words which are plainly inconsistent with the larger context. As it has appeared, the manuscripts selected offer in general a few errors.

\section{Inversions}

Inversions consist in the reversal of the word-order in a given sentence. While they are quite recurrent in the manuscripts I have taken into account, they do not modify the meaning of the text. As a general rule, I have therefore found reasonable and economically convenient to my purpose here to remove them from the apparatus. The rare exceptions which have been included concern just a small number of inversions, i.e., inversions combined with omissions and/or significant substitutions.

\section{Omissions}

All the omissions in all the manuscripts have been included in the apparatus. The reader will thus find what I have labelled long/short omission and genuine/conditioned omissions. ${ }^{59}$ Long omissions are omissions of three or more words (words $\geq 3$ ). Short omissions, in contrast, are omissions of two or

57 Thomas Wylton, On the Intellectual Soul (ed. Nielsen, Trifogli, 2010, pp. x-xxxi); John Wycliff, De Scientia Dei (ed. Campi, 2017, pp. 1xix-1xx).

58 Schabel, 2000, p. 155.

59 Although all the omissions (as well as substitutions and additions in all the manuscripts considered here) have been included in the apparatus, I still thought it appropriate to draw here the distinction between genuine and conditioned omissions (substitutions and additions), as it reflects the analysis work done on the manuscripts and may also provide useful (although provisional) indications of their quality, given the lack of a clear stemma and of a solid knowledge of the textual tradition of Auriol's commentary on Book II. 
fewer words (words $\leq 2$ ). Both long and short omissions are further divided into genuine omissions, when they cannot be explained for paleographical reasons, and conditioned omissions, such as omissions per homoteleuton. As a general rule, omissions are considered as errors, whenever they modify the text, by making it obscure and hard to understand.

\section{Additions}

As in the case of omissions, the additions of all the manuscripts have also been reported. The additions found in the apparatus comprise both long additions (words $\geq 3$ ) and short additions (words $\leq 2$ ). While long additions are rare, short additions are usually recurrent. Besides, note that the additions (either long or short) included in the apparatus comprise both what can be called (long/short) genuine additions (i.e., additions which cannot be explained on paleographical grounds) and (long/short) conditioned additions (i.e., dittographies or errors by polyptoton).

\section{Substitutions}

Substitutions are variants in the most canonical sense. As a general rule, only genuine substitutions have been included in the apparatus. Genuine substitutions are one or more words which are replaced by non-paleographically similar words, i.e., words that cannot be reduced to an error of the scribe, such as dittographies, errors by polyptoton and thereby alter the meaning of the text. Conditioned substitutions are one or more words that are replaced by paleographically similar words, which, in contrast, do not modify the general meaning of the text. The most frequent cases of conditioned substitutions concern the use of pronouns like ista/illa/ipsa/iste/ille/ipse etc. Since conditioned substitutions are quite common, while genuine ones are not, I have therefore found convenient to my purpose here to integrate Fb's text with just those (conditioned) substitutions, whose meaning, while being nearly the same with Fb's, provide the reader with a clearer understanding of the text. As it appears, these are just rare cases. Besides genuine substitutions, then, the apparatus will also include few conditioned ones.

In the apparatus, gaps (lacunae) are indicated as [ ]; integrations are indicated as $<>$. As to the ergo/igitur alternative, I have always opted for Fb's reading. 


\section{Petrus Aureolus}

Commentarium in II Sententiarum, d. 9, q. 1, art. 1

\section{De hierachiis et ordinibus eorum}

[1] Fb 38vb/Fc 39va/N 137rb/Pc 43vb/Pg 34va/Pj 150rb/Vg 29ra/Vi 30rb/ Postquam visum est de actibus hierachicis angelorum, videndum est nunc aliud de ipsis hierarchiis et ordinibus eorum, et primo quantum ad distinctionem. Et quia duplex distinctio reperitur in angelis, videlicet multorum angelorum unius ordinis et hierachiae ad invicem et ipsarum hierarchiarum et ordinum inter se, ideo primo videndum est de distinctione angelorum inter se unius hierachiae, quae est distinctio personalis. Et ut melius appareat propositum, videndum est in generali de distinctione individuorum sub specie, et primo de communitate naturae specificae in individuis, secundo de formali principio individuationis quod contrahit speciem ad determinatum individuum. Quantum ad primum quaero quattuor quaestiones. /X 103a/

Prima est utrum unitas specifica sit unitas alicuius rei communis extra animam in individuis existentis.

Secunda est utrum unitas specifica sit unitas rei indifferentis.

Tertia est utrum unitas specifica sit unitas tantummodo similitudinaria et qualitativa.

Quarta est utrum unitas specifica sit in re /Pc 44ra/ vel in intellectu tantum.

\section{Articulus primus}

[2] Quantum ad primam quaestionem arguo primo quod unitas specifica est unitas rei alicuius existentis extra intellectum sic quia impossibile

8 aliud] aliquid NPg om. Fc 9-10 multorum] malorum N 12-13 angelorum ... distinctione] om. Vg 14 specificae] om. Vg 15 individuationis] individuis add. $\mathrm{N}$ 16 determinatum] terminatum $\mathrm{Vg} \quad \mathbf{1 7}$ quaestiones] om. $\mathrm{N} \quad \mathbf{2 0}$ in $] \mathrm{om} . \mathrm{Vg} \mid$ individuis] individui $\mathrm{Vg} \quad \mathbf{2 2 - 2 3}$ tertia ... qualitativa] om. Fc 24 quarta] tertia Fc | in ${ }^{1}$ ] nam $\mathrm{Pj}$ 25 tantum] om. FcVg 29 quantum] $<\mathrm{q}>$ uantum $\mathrm{Fc} \mid$ quaestionem] om. FbFcNPcPjVg | arguo] om. N 30 unitas] uni[] Fc | existentis] ex[] Fc | quia] om. Vg 
est aliqua eadem realiter convenire et differre, sed si non detur unitas alicuius realis extra intellectum, sequitur quod aliqua eodem reali omnino conveniant realiter et realiter differant, quare etc. Minorem probo, quia haec albedo et haec albedo differunt inter se realiter et certum est quod 5 conveniunt realiter in albedine, circumscripto actu intellectus, magis enim ex natura rei convenit haec albedo cum hac albedine / $\mathbf{X ~ 1 0 3 b / ~}$ quam cum hac nigredine, et haec convenientia non est nisi in unitate specifica, igitur etc.

Contra. Si talis unitas rei alicuius daretur, esset unitas rei universalis,

10 sed universalia non sunt extra animam, quare etc., quia universalia in solis, nudis, purisque intellectibus secundum Aristotelem ut recitat Porphyrius.

Respondeo. Haec fuit opinio Platonis, quae duravit usque ad tempora Philosophi, in qua iudicio meo multi hodie $/ \mathbf{F c} 39 \mathbf{v b} /$ realiter incidunt. Dicunt ${ }^{i}$ enim quod alia est realitas in qua conveniunt Socrates et Plato,

15 et aliae sunt realitates per quas differunt; sed dimissis multis opinionibus ponam propositionem intentam primo, deinde instabo.

Propositio est ista: quod unitas specifica non potest esse unitas alicuius rei existentis extra / $\mathbf{N}$ 137va/ animam realiter in individuis. Hanc probo primo rationibus fundatis / $\mathbf{P j} \mathbf{1 5 0 v a /}$ super intentionem Philosophi,

20 deinde aliquibus aliis.

[3] Prima ratio est adducens ad impossibile, quia si talis unitas daretur, Deus non posset aliquod unum individuum sub una specie annihilare,

1 eadem] eandem $\mathrm{Vg}$ ita rem $a d d . \mathrm{Vg} \mid$ realiter] realitate $\mathrm{N}$ om. $\mathrm{Vg} \mid$ differre] distinctae $\mathrm{N}$ realiter $a d d . \mathrm{Vg} \quad 2$ realis] rei Fc extra $a d d . \mathrm{N}$ | eodem] eadem $\mathrm{FcN}$ | reali] realiter Fc realitate $\mathrm{N} \mathbf{3}$ minorem] minoris $\mathrm{Vg} \mid$ probo] probatio $\mathrm{Vg}$ 3-4 quia ... albedo $^{1}$ ] [] Fc $\mathbf{4}$ quod] quia $\mathrm{Vi} \quad \mathbf{5}$ realiter] naturaliter $\mathrm{N} \quad \mathbf{2}-\mathbf{5}$ quod ... albedine] [] Fc 7 convenientia] differentia Fc $\mathbf{1 0}$ universalia] sunt $a d d$. NPjVg $\mathbf{1 1}$ nudis] meris $\mathrm{FbPgVi} \mid$ recitat] tractat $\mathrm{FbPgVi} \mathbf{1 2}$ haec] hic $\mathrm{Fb} \quad \mathbf{1 3}$ qua] quam $\mathrm{NVg} \mathbf{1 4}$ quod] quia $\mathrm{Pg} 16$ ponam] pono $\mathrm{FcNVgVi} \mid$ primo] om. $\mathrm{PgVi} \mid$ deinde] om. $\mathrm{N}$ 17-18 alicuius] actus $\mathrm{Fc} 18$ in] om. Pc 19 intentionem] intentione FbN 21 adducens] ducens $\mathrm{Vg}$

${ }^{\text {i } ~ C f . ~ J o h n ~ D u n s ~ S c o t u s, ~ O r d i n a t i o, ~ I I, ~ d . ~ 3, ~ p a r s ~ 1, ~ q . ~} 1$ (ed. Balić, Barbarić, Bušelić, Hechich, Modrić, Nanni, Rosini, Ruiz de Loizaga, Saco Alarcón, 1973, nn. 29-42, pp. 402-410); John Duns Scotus, Lectura, II, d. 3, pars 1, q. 1 (ed. Modrić, Bušelić, Hechich, Jurić, Percan, Rosini, Ruiz de Loizaga, Saco Alarcón, 1982, nn. 28-38, pp. 236-239); cf. Walter Burley, Expositio libri De anima, lib. I, q. 3, Biblioteca Apostolica Vaticana, ms. Vat. lat. 2151, f. 10ra-vb; Roger Bacon, Quaestiones supra libros primae philosphiae Aristotelis (ed. Steele, 1930, pp. 241-244); cf. T. Wylton, Quodlibet, q. 5 (ed. Nielsen, Noone, Trifogli, 2003, p. 353: 341-348). 
quin eo ipso annihilaret omnia individua eiusdem speciei. Consequens est falsum, igitur etc. Probo consequentiam, quia si annihilaret totum individuum: aut tollit /Fb 39ra/ totam suam realitatem, et tunc cum realitas illa specifica sit in aliis individuis, quae /X 104a/ est in isto quod annihilatur, igitur oportet eam in aliis annihilari; vel si non, igitur tota entitas ipsius individui non est annihilata.

[4] Consimile argumentum in consimili forma sit quod Deus non poterit creare unum individuum nisi creet omnia individua illius speciei, quia creare est de nihilo facere. Tunc capio animam quae creatur. Quando creatur, quaero aut realitas aliqua communis est in anima alia quae prius fuit creata isti quae nunc creatur vel non. Si non, ergo nulla est communitas alicuius rei extra. Si erat iam in alia anima, igitur, cum in ista anima sit creata, quia anima ista creatur secundum totam suam realitatem, igitur in alia anima creatur, et sic in omnibus istis individuis.

[5] Dices quod ratio ista procedit ac si illa unitas esset unitas numeralis, quod non est de mente opinionis alterius, sed est unitas specifica et communis, et tunc verum est quod totum creatur in illo quod creatur, quod est unum unitate numerali. Similiter totum corrumpitur in illo quod corrumpitur quod est unum unitate numerali; et tamen adhuc manet ista alia realitas communis communitate specifica.

[6] Haec responsio confirmat propositum, quia illa realitas, quae est una existens /Vi 30va/ et eadem in multis, non tollit creationem unius sine alio, non potest esse realitas existens extra animam. Da enim quod esset extra animam: ex quo esset in alio iam posita, non posset creari de novo in isto, alias / $\mathbf{P c ~ 4 4 r b / i d e m ~ b i s ~ c r e a r e t u r , ~ c r e a r e ~ e n i m ~ e s t ~ d e ~ n i h i l o ~ f a c e r e ; ~}$ ista autem realitas secundum te iam praeest in alio.

2 si] om. Fc | totum] unum $a d d . \mathrm{Vg} \quad \mathbf{3}$ tollit] tollet $\mathrm{Vg} \quad \mathbf{6}$ ipsius] totius $\mathrm{Pg} \quad \mathbf{8}$ creet] crearet Pg | illius] ipsius Pg $\mathbf{1 0}$ aliqua communis] quae Vi | alia] illa $\mathrm{N}$ om. Vg 11 fuit] est communis $a d d$. Vi 12 extra] animam $a d d$. Fc | erat iam] [ ] Fc | in ${ }^{2}$ om. $\mathrm{PgVg} 13$ ista] illa FcNPcPg 14 alia] aliqua Vg | anima] non add. Vi | istis] om. Fb om. $\mathrm{Vg} 15$ ac] aliter $\mathrm{N} 18$ numerali] numerali $a d d$. $\mathrm{N} \mid$ corrumpitur] corpus $\mathrm{N}$ | illo] illud $N \quad 18-19$ in ... corrumpitur] om. Pc 19 corrumpitur] corpus $N$ | manet] remanet $\mathrm{Fc} \mid$ ista] illa $\mathrm{FbFcPcPjVg} \mathbf{2 1}$ propositum] propositionem | quia] si add. Vi | quae] quia $\mathrm{Fc}$ qua $\mathrm{N}$ | est] om. FbNPc 22 existens] una Fc om. $\mathrm{Vg}$ | eadem] ex add. $\mathrm{Fc} \mid$ sine] secundum $\mathrm{Fb} \quad \mathbf{2 4} \mathrm{ex}]$ a $\mathrm{N} \quad \mathbf{2 5}$ in isto] alio Vi 26 ista] alia FcPc $\mid$ autem ] enim Vi | praeest] sed $\mathrm{N}$ 
[7] Secunda ratio est Philosophi, 7 Metaphysicae, quia si ponatur aliqua talis res communis in pluribus, sequeretur quod in homine essent duae humanitates. Hoc est falsum, quia tunc unus homo esset duo homines. Probo consequentiam, quia homo iste datus particularis per

5 te habet humanitatem, veram rem quae est communis alteri. Certum est autem quod habet humanitatem propriam quam nullus alius habet, quia substantia cuiuslibet rei est propria sibi, sicut substantia qua Socrates est Socrates est propria sibi. Cum igitur Socrateitas sit quaedam humanitas, quia Socrates in existendo est quidam homo, igitur humanitas Socratis

10 est substantia Socratis; et sic dicam de Platone /Pg 35ra/. Igitur quilibet est homo per propriam humanitatem. Sed secundum te est alia communis istis, igitur etc.

[8] Sequitur etiam ex hoc consequenter quod sit dare tertium hominem /Vg 29rb/a Socrate et Platone— hoc est inconveniens, ad quod Aristoteles

15 adducit, 7 Metaphysicae. ${ }^{\mathrm{ii}}$

[9] Dices: illa communis realitas non est humanitas distincta ab ista, sed fit propria et determinata per proprietatem hypostaticam isti, quae quidem proprietas trahit eam ad esse individui, et ideo individuum super illam non dicit aliam humanitatem, sed tantum dicit proprietatem illam

20 contrahentem, et ambo sunt una propria substantia ipsius individui.

[10] Haec solutio non valet, quia quaero post illam appropriationem factam utrum sit verum dicere quod aliqua res sit communis Socrati et Platoni vel non. Si sic, cum illa humanitas appropriata per te sit communis, sequitur quod Socrates et Plato non differant /X 104b/substantialiter, sed

25 solum hypostatice, quia per proprietatem hypostaticam qualis distinctio

3 duae] differentiae Pc 7 socrates] si socrates add. et del. Pg 7-8 sicut ... propria] om. $\mathrm{N} \quad \mathbf{8}$ est] socrates $a d d . \mathrm{Vg} \mid$ sibi] om. $\mathrm{FcN} \mid$ sit] om. $\mathrm{N} 9$ quidam] om. $\mathrm{N}$ | humanitas] substantia N $\mathbf{1 1}$ alia] [] Fc alias N $\mathbf{1 3}$ sequitur] [] Fc | consequenter] cum dicitur Fc om. $\mathrm{N} \quad 14$ inconveniens] id est $a d d . \mathrm{Vg} \mathbf{1 6}$ communis] haec add. $\mathrm{Vg} \mid$ ab ista] ad istam $\mathrm{N}$ | ista] illa Pg $17 \mathrm{sed}] \mathrm{si} a d d . \mathrm{N} \mid$ propria] om. $\mathrm{Vg} \mid$ isti] istis $\mathrm{PcPj} \quad 18$ individuum] dividuum $\mathrm{NPj} \quad 20$ substantia] extra add. $\mathrm{Pj}$ | contrahentem ... ipsius] [ ] Fc 21 non valet] [ ] Fc | illam] istam $\mathrm{FbPjVg} 22$ dicere] om $\mathrm{Pg} \mid$ quod ... res] [] Fc 23 si sic] om. $\mathrm{N} \mid$ sic] sit $\mathrm{Fb} \mid$ cum] tamen $\mathrm{N} \mid$ illa ... sit] [ ] Fc 24 differant] differunt $\mathrm{FbN} \quad \mathbf{2 4 - 2 5}$ substantialiter ... proprietatem] [] Fc 25 quia] qua $\mathrm{Fb}$

${ }^{\text {ii }}$ Cf. Aristoteles, Metaphysica, Z, 6, 1032a 2-4; Z, 13, 1039a 2-3; cf. Aristoteles Latinus, Metaphysica, lib. I-XIV. Recensio et Translatio Guillelmi de Moerbeka, lib. 7, cap. 13 (ed. Vuillemin-Diem, 1995, p. 159: 749-750). 
ponitur inter personas in divinis. Si dicis quod, facta appropriatione et determinatione, non remanet communis sed haec, et prima est alia $/ \mathbf{P j} \mathbf{1 5 0 v b / t o t a l i t e r , ~ t u n c ~ s e q u i t u r ~ q u o d ~ v e l ~ n u l l a ~ e r i t ~ r e a l i t a s ~ c o m m u n i s , ~}$ vel si sit aliqua alia communis ab illa propria humanitate, tunc unus homo erit duo homines, ut prius.

[11] Tertia ratio est, quia sicut ponitur secundum hoc una natura communis extra intellectum, ita per eandem rationem oportet ponere de omnibus generibus, et sic erit animalitas communis extra intellectum, et similiter corporeitas, et sic de aliis. Consequentiam probo, quia Socrates et Brunellus realiter conveniunt in animalitate, circumscripto omni intellectu, plus convenit Socrates cum Brunello quam cum planta. Hoc non potest esse nisi sit unitas alicuius rei extra animam in qua conveniunt Socrates /Fb 39rb/ et Brunellus. Consequentia est falsa, quia sic essent multae substantiae distinctae in una substantia, impossibile est autem quod una substantia per se constituatur ex pluribus substantiis distinctis, sed homo est per se una substantia, igitur etc.

[12] Quarta ratio est ista: quaero de ista realitate communi aut praedicatur identice et formaliter de ista realitate propria et de qualibet cui est communis aut non. Verbi gratia: ut utrum sic praedicetur homo de Socrate et Platone quod verum sit dicere 'haec humanitas est Socrateitas' et e converso, aut non praedicatur identice de ipsis ut non sit verum dicere quod humanitas sit Socrateitas et Platoneitas, sed sit res quaedam in Socrate et Platone. Non potest dari primum, quia tunc una res praedicaretur identice de pluribus differentibus realiter, quod nos male intelligimus etiam in divinis, immo esset quasi una res /Pc 44va/ communis realiter pluribus, sicut est in divinis. Nec potest dari secundus modus, quia tunc cognoscendo humanitatem, nihil in toto mundo cognoscerem de Socrateitate, quia alia /N 137vb/ omnino est.

1 dicis] dicas $\mathrm{Pj} 2$ prima] illa FbPjVi 1-3 ponitur ... totaliter] [ ] Fc 2-3 sed ... communis] om. $\mathrm{N} 4$ si sit] significat $\mathrm{Fb} /$ illa] ipsa $\mathrm{FbPj}$ [ ] Fc $\mathbf{5}$ ut prius] om. $\mathrm{Vg} \quad \mathbf{6}$ est] om. FbFcNPcPjVi 7 ita] item $\mathrm{N} \quad \mathbf{8}$ et $\left.^{2}\right]$ ut FcNPc 9 similiter] sic add. Vg 10 omni] enim $\mathrm{Fb} 12$ potest] om. Pc | esse] om. Vg | nisi] sit Fc om. $\mathrm{N} \mid$ sit] potest $\mathrm{Fc} \mid$ animam in] om. Fc 13 et] plato add. $\mathrm{Pj} 14$ distinctae] discretae $\mathrm{Fb} 15$ distinctis] discretis $\mathrm{Fb}$ om. NVi 17 ista $^{2}$ ] illa FcNPcPg | aut] ut $\mathrm{Pj} 18$ ista] illa FcNPcPg | realitate] identice Fc 19 communis] om. Fc | homo] et add. $\mathrm{Pj} 22$ socrateitas] sortalitas $\mathrm{N} \mid$ et] vel $\mathrm{N} \mid$ quaedam] quadam $\mathrm{Vg} 25$ quasi] quod $\mathrm{Fc} \quad \mathbf{2 6} \mathrm{nec}]$ non $\mathrm{Fb} \quad 27$ cognoscerem] cognosceret VgVi 27-28 socrateitate] socrate $\mathrm{Vg}$ om. Vi 28 alia] alius $\mathrm{N}$ 
[13] Confirmatur, quia si est communis, tunc quando Socrtaes generat Platonem, vel non generaret totum Platonem, vel idem generaret se, nisi dicatur quod generatio non est aliud quam communicatio essentiae per transfusionem in alio, sicut dicimus de essentia in divinis. Et haec

5 est ratio Aristotelis: $:$ ii generans enim non generat idem, sed generat tale, quale ipsum est.

[14] Nunc pono instantias et difficultates quae occurrunt circa hoc. Et prima quidem est quia omni uni potentiae correspondet unum obiectum formale sub una ratione, ${ }^{\text {iv }}$ sed visus est una potentia circumscripto actu

10 intellectus, igitur correspondet sibi unum obiectum formale sub una ratione. Illud est color et non hic color, igitur color, in quantum abstrahit ab hoc colore, est aliud in rerum natura. Probatio minoris, quia si hic color sub ratione huius coloris esset obiectum visus, non posset visus cognoscere $/ \mathbf{V i ~ 3 0 v b / a l i q u i d ~ n i s i ~ s u b ~ r a t i o n e ~ h u i u s ~ c o l o r i s ~ s i g n a t i . ~ E t ~ c o n f i r m a t u r , ~}$

15 quia sensus non decipitur circa proprium obiectum, sed visus decipitur circa unitatem numeralem obiecti, igitur color sub unitate numerali non est obiectum formale ipsius visus. Probo assumpta, ${ }^{v} / \mathbf{X}$ 105a/ quia visus tendit in radium solarem, qui continue est alius et alius, sicut in unum radium, igitur non attingit visus radium ut hic radius est, sed ut radius 20 in communi.

2 non] om. Vg | generaret $^{1}$ ] generat FcNPgVi | se] om. Vg 4 de... in] om. Fc | essentia] individuum $a d d . \mathrm{Vg} \mid$ divinis] divinum $\mathrm{Fb} \quad 7$ pono] propter $\mathrm{N} 9$ formale] formaliter $\mathrm{N} \mid$ sub] sed $\mathrm{N} \mid$ actu] in $a d d$. N $\mathbf{1 0}$ intellectus] intellectu $\mathrm{N} \mathbf{1 1}$ igitur] sed $\mathrm{N}$ | igitur color] om. $\mathrm{PgFc} 12$ aliud] aliquid $\mathrm{FcPc} \mid$ probatio] probo $\mathrm{N} \mid$ minoris] minorem N 14 coloris] corpus Pc 15 quia] quod $\mathrm{Pg}$ | proprium] propositum $\mathrm{N}$ 16 numeralem] add. ut $\mathrm{Vg} 18$ radium] radicem $\mathrm{Fb} \mid$ qui] nisi $\mathrm{N} \quad 19$ visus] om. $\mathrm{Vg}$

${ }^{\text {iii }}$ Cf. Aristoteles, Metaphysica, Z, 8, 1033b 16-30; cf. Aristoteles Latinus, Metaphysica, lib. I-XIV. Recensio et Translatio Guillelmi de Moerbeka, lib. 7, cap. 13 (ed. Vuillemin-Diem, 1995, pp. 146-147: 391-410).

iv Cf. Aristoteles, De anima, B, 4, 415a 16-20; cf. Aristoteles Latinus, De anima. Recensio Guillelmi de Morbeka, lib. 2, cap. 6 (ed. Gauthier, 1984, p. 91: 6); cf. John Duns Scotus, Quaestiones super libros Metaphysicarum Aristotelis, lib. 7, q. 13 (ed. Andrews, Etzkorn, Gál, Green, Kelley, Marcil, Noone, Wood, 1997, n. 71, p. 243).

v Cf. John Duns Scotus, Ordinatio, II, d. 3, pars 1, q. 1 (ed. Balić, Barbarić, Bušelić, Hechich, Modrić, Nanni, Rosini, Ruiz de Loizaga, Saco Alarcón, 1973, nn. 22-27, pp. 400-401); John Duns Scotus, Lectura, d. 3, pars 1, q. 1 (ed. Modrić, Bušelić, Hechich, Jurić, Percan, Rosini, Ruiz de Loizaga, Saco Alarcón, 1982, nn. 19-21, pp. 234-235). 
[15] Secundo sic. Haec est vera: 'Socrates est homo'. Quaero tunc aut praedicatur pura ratio fabricata per intellectum, aut Socrateitas de Socrateitate (sive Socrates de seipso), aut res realiter distincta et disparata, aut res communis non realiter distincta.

[16] Non potest dari primus modus, quia tunc una ratio fictitia praedicaretur de vera re. Nec secundus modus videtur possibilis, quia tunc praedicaretur idem de se et non esset aliud dicere 'Socrates est homo' quam 'Socrates est Socrates'. Nec potest dari tertius modus, /Pg 35rb/ quia tunc propositio esset falsa, nam hoc modo res distincta praedicaretur de re distincta praedicatione, quae dicit 'hoc est hoc'. Oportet ergo dare quartum: quod illud quod praedicatur ibi sit res ipsa aliquo ei addito, quo est Socrates /Pj 151ra/.

[17] Tertio, quia definitio est vere alicuius definibilis rei verae, quia non definitur pura ratio, tunc sic: illud habet veram entitatem realem quod vere definitur, sed definitio est unitatis specificae, non individui, igitur etc.

[18] Quarta ratio est ista. Cuicumque reali passioni correspondet subiectum adaequatum, ex primo Posteriorum, ${ }^{\text {vi }}$ sed risibilitas est passio realis, igitur habet subiectum adaequatum primum reale. Hoc non est aliquod individuum, quia non sibi adaequatur, ergo est aliquod commune, puta natura speciei.

[19] Quinta ratio est ista: illud a quo incipit divisio realis est vere entitas realis habens unitatem realem, sed realis divisio incipit a ratione generis / Vg 29va/, et sic per differentias reales, igitur in genere erit aliqua unitas realis.

2 aut $^{1}$ ] quod $\mathrm{Pj} \quad \mathbf{3}$ socrateitate] socrate $\mathrm{FcNPcPgPj} \mid$ sive] aut $\mathrm{Vg} \mathbf{4}$ disparata] separata $\mathrm{FcNPcPgPj} 5$ dari] dici $\mathrm{FcPcPg} \mid$ fictitia] [ ] Fc $\mathbf{6}$ vera] una $\mathrm{N} \mid$ secundus] unus $\mathrm{N} \quad 7$ idem] socrates $\mathrm{Pg} \mid$ et non] nec Vi $\mathbf{8}$ tertius] secundus Vi 9 esset] est Vi 11 quod $^{1}$ ] quia $\mathrm{N} \mid$ res] ad ipsum $a d d$. $\mathrm{Vg} \mid$ ipsa] idipsa $\mathrm{FbFcPc}$ ad ipsam $\mathrm{N}$ om. $\mathrm{Vg}$ alia ab ipsa $\mathrm{Vi} 12$ quo] alio $a d d$. N sortes $a d d$. Vg 13 vere] vera Vi | verae] om. Vg 14 entitatem] identitatem $\mathrm{Vg} \mid$ quod] quae $\mathrm{N} 19$ aliuquod ${ }^{1}$ ] quantum $a d d . \mathrm{Vg}$ 21 ista] illa Fc om. Pc 22 realis $^{1}$ ] om. Vi

${ }^{v i}$ Cf. Aristoteles, Analytica Posteriora, I, 7, 75a 23; cf. Aristoteles Latinus, Analytica posteriora. Translationes Iacobi, Anonymi sive 'Ioannis', Gerardi et Recensio Guillelmi de Moerbeka, lib. 1, cap. 7 (ed. Minio-Paluello, Dod, 1968, p. 293: 26). 
[20] Sexta sic: quando aliqua comparantur in una forma, oportet illa habere unitatem realem, unde 7 Physicorum $^{\text {vii }}$ comparatio non est secundum genus propter aequivocationem. Sed in /Fb 39va/ dividua comparantur secundum unitatem specificam, igitur illa erit realis.

[21] Septima sic:viii cuilibet rationi mensuranti convenit aliqua unitas, 10 Metaphysicae ${ }^{\mathrm{ix}}$ sed ratio mensurae convenit rei secundum rationem /Pc 44vb/specificam, non secundum rationem individui, nam unum individuum respectu alterius non habet rationem mensurae, cum inter individua non sit magis vel minus, prius vel posterius, ${ }^{\mathrm{x}}$ igitur ratio

10 specifica habet propriam aliquam unitatem. Sed unitas mensurae non est unitas rationis, ergo etc.

[22] Haec sunt rationes fundamentales cuiusdam opinionis, quae fuit valde communis et famosa usque ad tempora Aristotelis, et fuit opinio Platonis. Sed secundum rei veritatem non fuit opinio Platonis quod ideae

15 essent separatae subiecto et loco, sed erant separatae separatione reali, quia erant realiter aliud ab individuis quibus erant communes, et erant

1 sexta] secundo $\mathrm{Fc}$ sexto $\mathrm{Vi} \mathbf{3}$ aequivocationem] aequivocationes $\mathrm{N}$ aequipollentiam Pc 4 secundum] sed Vg 5 septima] tertio Fc | mensuranti] mensurati $\mathrm{Pg} \mid$ convenit] om. $\mathrm{N} \quad \mathbf{6}$ 10] 4 NPc 7 rationem ${ }^{1}$ ] naturam $\mathrm{FcPc} \quad \mathbf{9}$ vel $^{1}$ ] et $\mathrm{PjVgVi} \mid$ vel $^{2}$ ] et $\mathrm{VgVi} \mid$ posterius] post $\mathrm{Fb}$ prius $\mathrm{N} \mathbf{1 2}$ haec] hoc $\mathrm{Pg} \mathbf{1 3}$ valde ... fuit] om. Fc 14 sed] om. FbFcNPcPjVi | non] enim add. FbFcPcVgVi | ideae] ipsae $a d d . \mathrm{Vg} 16$ aliud] om. N

${ }^{v i i}$ Cf. Aristoteles, Physica, H, 4, 248b; cf. Aristoteles Latinus, Physica. Translatio Vetus, lib. 7, cap. 4 (ed. Bossier, Brams, 1990, pp. 269-270: 5-10).

viii Cf. John Duns Scotus, Ordinatio, II, d. 3, pars 1, q. 1, (ed. Balić, Barbarić, Bušelić, Hechich, Modrić, Nanni, Rosini, Ruiz de Loizaga, Saco Alarcón, 1973, nn. 11-15, pp. 396-397); John Duns Scotus, Quaestiones super libros Metaphysicarum Aristotelis, q. 13 (ed. Andrews, Etzkorn, Gál, Green, Kelley, Marcil, Noone, Wood, 1997, n. 70, pp. 242-243).

${ }^{\text {ix }}$ Cf. Aristoteles, Metaphysica, I, 4-6, 1053a 37-1054b 9; cf. Aristoteles Latinus, Metaphysica, lib. I-XIV. Recensio et Translatio Guillelmi de Moerbeka, lib. 10, cap. 13 (ed. Vuillemin-Diem, 1995, pp. 146-147: 391-410).

${ }^{x}$ Cf. Aristoteles, Praedicamenta, 2b 7-3a 6; cf. Aristoteles Latinus, Categoriae vel Praedicamenta. Translatio Boethii, Editio Composite, Translatio Guillelmi de Moerbeka, Lemmata e Simplicii commentario decerpta, Pseudo-Augustini Paraphrasis Themistiana, cap. 5, pp. 8-9; pp. 88-89 (ed. Minio-Paluello, 1961); cf. Simplicius, Simplicii In Aristotelis Categorias commentarium (ed. Kalbfleisch, 1907, pp. 89-90); cf. Simplicius, Simplicius in Categorias, cap. 5 (ed. Pattin, vol. 1, p. 121: 26-55). 
hoc modo ingenerabiles et incorruptibiles et per communicationem talis realitatis communis isti et illi, et iste et ille erant homines et sic de aliis individuis aliarum specierum. Et hunc intellectum tangit Philosophus, 2 De generatione et corruptione, ${ }^{\mathrm{xi}}$ qui dicit quod apud istos generatio fiebat per ingressum et / $\mathbf{X} \mathbf{1 0 5} \mathbf{b}$ / egressum, et ita mens eorum erat quod idea erat realitas intra individuum, sed tamen extra, non per separationem localem, sed entitativam, quia realiter distincta ab individuo. Et realitas istius ideae communis fiebat huius et illius particularis per materiam contrahentem, et hoc modo Callias et Socrates non differunt nisi per materiam, et sic procedit Aristoteles contra istam opinionem ad istum intellectum, 7 Metaphysicae. ${ }^{\mathrm{xii}}$

[23] Ad difficultates quae adduncuntur dico quod omnes procedunt ex rationibus communibus et logicis, et ideo sunt difficiles ad solvendum, tamen ex rationibus logicis non debet iudicari verum, posito quod appareat aliquod inconveniens secundum rationem logicam.

[24] Tunc ad primum dico quod ratio supponit falsum, scilicet quod actus sensationis terminetur ad aliam realitatem quam individui;

1 hoc modo] omnimo Fc ideo $\mathrm{N}$ huiusmodi Vg ideae omnino add. Vg | communicationem] communitatem $\mathrm{N} 2$ communis] om. $\mathrm{N} \mid$ et iste] om. Pc | et ${ }^{3}$ ] om. $\mathrm{FcPgPj} 4$ qui] cum $\mathrm{FbPjVgVi} \mid$ istos] illos $\mathrm{Pg} \quad \mathbf{5}$ et $^{2}$ ] om. FbNPcPjVi | ita] quod add. FbPcVg 6 tamen] cum hoc Fc | extra] scilicet individui add. Fc | per] sed N 7 sed] om. $\mathrm{N} \mid$ realiter] formaliter $\mathrm{Vi}$ | individuo] individua $\mathrm{N} \mathbf{8}$ huius] haec FcN$\mathrm{PcPjVgVi} \mathrm{|} \mathrm{illius]} \mathrm{illa} \mathrm{FcNPcPjVgVi} \mathrm{|} \mathrm{fiebat} \mathrm{...} \mathrm{particularis]} \mathrm{et} \mathrm{hoc} \mathrm{modo} \mathrm{callias} \mathrm{et}$ socrates Fb 10 istam] unam Pc 11 intellectum] intellectus $\mathrm{Vg} \mid$ metaphysicae] est nunc $a d d$. Fc tunc $a d d$. NPcPgVi 12 dico] contra istam opinionem $a d d$. Vg 13 rationibus] rebus $\mathrm{Fb} \mid$ communibus] quibusdam $\mathrm{Fc} \mid$ et $\left.^{1}\right]$ om. $\mathrm{FbVgFc} \mid$ logicis] locis $\mathrm{Pg}$ 14 debet] habet $\mathrm{Vg} \mathbf{1 6}$ primum] argumentum add. Fc autem add. $\mathrm{N} \mid$ scilicet] om. FcPcPgVg 17 actus] ratio FcPc

${ }^{x i}$ Cf. Aristoteles, De generatione et corruptione, B, 9, 335b 8-24; cf. Aristoteles Latinus, De generatione et corruptione. Translatio Vetus, lib. 2, cap. 9 (ed. Judycka, 1986, pp. 73-74); cf. Aristoteles Latinus, De generatione et corruptione. Recensio Guillelmi de Moerbeka, lib. 2, cap. 9 (ed. Judycka, 2003).

xii Cf. Aristoteles, Metaphysica, Z, 8, 1034a 4-8; cf. Aristoteles Latinus, Metaphysica, lib. I-XIV. Recensio et Translatio Guillelmi de Moerbeka, lib. 7, cap. 8 (ed. Vuillemin-Diem, 1995, p. 147: 416-419). 
secundum enim Aristotelem ${ }^{\text {xiii }}$ intellectus est universalium, sensus vero particularium, et ideo radius qui terminat visum est hic radius numeralis.

[25] Tunc ad formam: cum dicitur "uni potentiae /N 138ra/ correspondet unum formale obiectum," dico quod potentia comparatur ad

5 obiectum per actum suum mediante quo attingit obiectum. Sicut igitur est de actibus individuis in ordine ad obiectum, sic de potentia ad actum; sicut igitur actus numeraliter sunt distincti et habent unitatem specificam, sic a parte obiecti color, qui aspicit actus numeraliter distinctos, est hic color et hic color secundum unitatem numeralem. Color vero qui aspicit

10 actus ut sunt unum specie habet unitatem communem speciei sive generis, sic ergo unitas obiecti correspondet unitati potentiae mediante actu, et ideo mediante actu numerali respicit hunc colorem numeralem. Mediante vero actu communi respicit colorem secundum rationem communem, secundum autem /Vi 31 ra/ rationem specificam actus est obiectum color

15 abstractus, quam quidem abstractionem non facit sensus, sed intellectus, et per consequens intellectus est qui dat sibi illam unitatem.

[26] Ad illud de radio, quod visus non $/ \mathbf{P j} \mathbf{1 5 1} \mathbf{r b} /$ decipitur in unitate propria /Pg 35va/ sui obiecti formalis, concedo, et ideo actus ille numeralis non decipitur circa hunc radium. Quot enim sunt radii, tot sunt visiones, et

20 ideo sicut annihilatur et evanescit radius, sic annihilatur et evanescit visio quae erat respectu illius. Et cum dicit "sensus iudicat per totum decursum esse unum radium", nego de sensu particulari, sed verum est de sensu communi, ille enim iudicat esse unum radium, et ratio est quia omnes /Pc 45ra/ sunt apti facere unam impressionem, /Fc 40va/ et sunt similia

2 qui ... numeralis] qui terminat visum est hic radius numeralis add. $\mathrm{Fc} \mid$ numeralis] universalis $\mathrm{N} 5$ quo] qua $\mathrm{FbNPcPj} \quad \mathbf{5}-\mathbf{6}$ sicut ... actum] om. Vi $\mathbf{6}$ ad actum] om . FcNPcPgVg 7 actus] actus $a d d$. Fc communi $a d d$. FcPgVg | sunt] om. Vi | distincti] distincta $\mathrm{N}$ | et] om. $\mathrm{PgVi}$ | et habent] ad hanc $\mathrm{FcN}$ | unitatem] uniformalitatem $\mathrm{Pj}$ | specificam] distinctam $\mathrm{FcNPcPg} \quad \mathbf{8}$ qui] quae $\mathrm{Fb} \quad \mathbf{9}$ hic color $]$ om. $\mathrm{Vg} \mid$ vero] om. $\mathrm{Fc}$ enim Pg 11 et] om. N 12 numeralem] sed add. PgVgVi 12-13 mediante ... communem] om. Vi 13 vero] om. $\mathrm{Pg}$ | communi] qui $a d d$. Vg 14 actus] alicuius N 17-19 in ... decipitur] om. $\mathrm{N} 19$ circa] contra $\mathrm{N} 20$ ideo] om. FbPjVgVi | visio] om. $\mathrm{N}$ 23 iudicat] deiudicat Fc dicat $\mathrm{N} \mid$ radium] om. Pg 24 et] om. $\mathrm{Pg}$

${ }^{\text {xiii }}$ Cf. Aristoteles, Analytica Posteriora, A31, 87b 37-39; cf. Aristoteles Latinus, Analytica posteriora. Translationes Iacobi, Anonymi sive 'Ioannis', Gerardi et Recensio Guillelmi de Moerbeka (ed. Minio-Paluello, Dod, 1968, p. 317: 10-11); cf. Les Auctoritates Aristotelis (ed. Hamesse, 1974, p. 319). 
et eiusdem rationis. Et ideo ibi decipitur sensus communis, sed non sensus particularis, cuius hic radius est proprium obiectum, ut hic et hic.

[27] Ad illud de praedicatione dico quod non praedicetur alia res quam Socrateitas, cum dicitur /Fb 39vb/ 'Socrates est homo'. Ad inconveniens quod adducitur quod idem praedicaretur de se, dico quod quantum ad rem ita est vere, enim secundum rem eadem est res quae ponitur in subiecto et quae ponitur in praedicato. Sed loquendo de re in ordine ad intellectum qui cognoscit eandem rem alio et alio conceptu, cum accipit Socratem ut Socratem et ut hominem-quaelibet enim res singularis /X 106a/ nata est facere de se alium et alium conceptum, et unum notiorem altero, per quem declarat illum - et sic eadem res sub conceptu noto praedicatur de se sub conceptu ignoto, est enim res omnino una sub utroque conceptu, et intellectus ponit per eandem similitudinem confusam omnia individua $<$ sub $>$ unum conceptum specificum.

[28] Dices ergo pura ratio et purus conceptus praedicabitur de vera re, et erit falsa praedicatio.

[29] Respondeo: rationem praedicari de re potest intelligi dupliciter. Uno modo quod pura ratio praedicetur sic quod sit illud quod praedicatur, et tunc curret inconveniens /Vg 29vb/ quod adducitur. Secundo modo quod ratio non praedicetur, sed sit aliquid inclusum necessario in praedicato, quia cum praedicatio sit actus intellectus, impossibile est rem praedicari nisi sub concipi passive, et tunc praedicatio est impossibilis nisi praedicatum et subiectum accipiantur sub alio et alio concipi, qui faciunt alium et alium conceptum, et per consequens aliam et aliam rationem, et sic res est quae praedicatur, concipi autem est illud quod concurrit ad illud quod subicitur et quod praedicatur. Et sic totum praedicatur de toto. Nec propter hoc est praedicatio entis per accidens, quia non potest intellectus praescindere intelligi rem et suum concipi sine contradictione. De hoc quaero plenius cum agebatur de ratione generis et differentiae. ${ }^{\text {xiv }}$

$\mathbf{1}$ rationis] om. Fc $\mathbf{2}$ cuius] et sunt $\mathrm{Fc} \quad \mathbf{3}$ praedicetur] praedicatur $\mathrm{FbPcPj} \quad \mathbf{8} \mathrm{rem}] \mathrm{sub}$ add. $\mathrm{Vg} 9 \mathrm{res}] \mathrm{om} . \mathrm{Vi} \mathbf{1 0}$ alium et] om. $\mathrm{N}$ | et... conceptum] om. Fc | notiorem] nobiliorem $\mathrm{Vg} 11$ quem] quam $\mathrm{Pg} 15$ pura] puta $\mathrm{Fb} 17$ respondeo] dico $\mathrm{Vi}$ | rationem] rei $\mathrm{Vi} 18$ quod $^{2}$ ] om. Fb non add. $\mathrm{Vg}$ | sit] om. Fb 19 curret] curreret $\mathrm{PcPj}$ 22 concipi] conceptu $\mathrm{Pg} 25$ quae] qua $\mathrm{N}$ | praedicatur] ponitur Fc | autem] aut $\mathrm{PgFc} \mid$ concurrit] concipit FcNVgVi | illud $\left.{ }^{2}\right]$ idem N 26 et $\left.^{2}\right]$ quod add. et del. $\mathrm{Fb}$ 28 intelligi] intellectus Pc inter Vi $\mathbf{2 9}$ quaero] dictum est Pg quaesivi Vg quaerebatur Vi

${ }^{\text {xiv }}$ Cf. Petrus Aureoli, II Sententiarum, d. 3, q. 2, art. 4 (Fb, ff. 25va-27vb). 
[30] Dico igitur quod quando ibi praedicatur homo de Socrate et Platone, homo non est res alia a Socrate et Platone, nec tamen est una res in ipsis nisi unitate rationis, quae consistit in uno concipi, quia omnes istae res, puta Socrates et Plato, et sic de aliis, conveniunt in uno concipi

5 passive, et ideo sub illa ratione attinguntur unica intellectione et uno intelligi. Et ideo est una ratio quae non est aliud quam unitas conceptus, nec istud concipi, ut dictum est alias, ${ }^{\mathrm{xv}}$ respicit rem ut substratum, sed per indivisionem, quia intellectus rem concipi non potest resolvere in duo, sed quantumcumque accipiat rem praecise, semper ibi includit concipi.

10 [31] Ad aliud de definitione, dico quod definitio vera est singularium, ut Commentator dicit 2 De anima, commento $8,{ }^{\text {xvi }}$ exponens mentem Aristotelis fuisse istam.

[32] Sciendum igitur quod circa rem circa quam intellectus negotiatur est duo considerare, scilicet rem ipsam et operationem intellectus. Defi-

15 nitio autem, cum sit actus intellectus, oportet esse in diffinitione et rem ipsam et operationem intellectus. Res igitur, quae ibi est, est singularis et particularis, sed quia ibi concurrit operatio intellectus, ideo definitio est rei secundum communem conceptum quem res illa facit. Sic ergo ibi diffinitio est rei particularis, sed secundum coexplicationem unitatis

20 quam facit intellectus. Diffinitio est rei sub concipi.

[33] Ad illud de passione quod habet subiectum adaequatum respondeo: sic est de passionibus, /Pc 45rb/ sicut de subiectis, quia sicut hic homo et hic homo faciunt unum communem conceptum, /Pj 151va/ quia quodlibet istorum est res cum tali concipi, sic haec risibilitas et haec.

25 Et ideo haec risibilitas adaequatur huic humanitati et illa illi. Risibilitas

1 igitur] om. FcPc sic N | quando] om. Pc | ibi] om. FbFcNVi autem Pc 3 quae] [ ] Fc om. $\mathrm{N} \mid$ quia] igitur add. $\mathrm{Pg} \mid$ omnes] om. $\mathrm{Pg} 5$ attinguntur] sub add. $\mathrm{Vg}$ 6 aliud] ad $\mathrm{N} \quad 7$ alias] et $a d d . \mathrm{Pg} \quad \mathbf{8}$ rem] esse et $\mathrm{Fb} \quad \mathbf{1 0}$ quod] om. $\mathrm{N}$ | vera] negativa $\mathrm{FcPcVg} 14$ ipsam] illam FcPcPg 15 et] om. Fc 16 ipsam] illam PgFc istam $\mathrm{N}$ | res] om. $\mathrm{N} 18$ quem] quam $\mathrm{Fc}$ | sic] si Fb 19 ibi] om. FbN add. et del. $\mathrm{Pg}$ | coexplicationem] participationem FcPc explicationem NPgPjVgVi 22 est] om. Pg | subiectis] substantiis $\mathrm{Pg} 24$ istorum] illorum $\mathrm{PgFc} \mid$ res] om. N 25 haec] scilicet Vg

${ }^{x v}$ Cf. Petrus Aureoli, Scriptum I, d. 23, art. 2 (ed. De Rijk, 2005, pp. 718-719; pp. 737-738).

${ }^{x v i}$ Cf. Averroes, Commentarium Magnum in Aristotelis De anima libros, II, comm. 8 (ed. Crawford, 1953, pp. 142-143). 
autem simpliciter adaequatur humanitati simpliciter ita quod quaelibet realitas sit sub uno communi /X 106b/ concipi passive. Et sic adaequantur passiones subiectis proportionaliter hinc inde. /Pg $35 \mathrm{vb} /$

[34] Ad aliud de divisione reali /N 138rb/ concedo maiorem et minorem nego, illa enim non est realis divisio per differentias, nec incipit ab unitate rei absolute, sed ut cadit sub concipi.

[35] Ad illud de comparatione dico quod comparatio fit secundum unitatem conceptus, non rei.

[36] Ad probationem de Philosopho dico quod si illa esset intentio Philosophi, ita diceret quod comparatio sit secundum genus, sicut secundum speciem; nam /Fc 40vb/generi, secundum istos, correspondet propria /Vi 31rb/ realitas quam non importat /Fb 40ra/ differentia, et rationes suae aliquae potissimae, ita probant de genere, sicut de specie. Et tamen Philosophus negat comparationem secundum genus, et concedit secundum speciem.

[37] Dico ergo quod ad comparationem sufficit unitas in concipi, sub qua intellectus ponens omnia potest comparare illa in illa ratione conceptus. Potest enim intellectus habere unam speciem omnium individuorum, et ideo potest habere actum unum, et per consequens unum concipi et unum conceptum generis, et secundum illum erit comparatio.

[38] Sed quare non sic sit comparatio individuorum secundum unum conceptum generis, sicut speciei, respondeo: unitas conceptus generis provenit a quodam concipi diminuto et imperfecto, qui sequitur actum imperfectum, qui est a specie quadam diminuta proveniente ab imperfecta impressione quam nata sunt facere individua in intellectu. Et hinc est quod conceptus generis expectat semper differentiam contrahentem, quia non est secundum concipi simpliciter sed imperfectum. Et hinc est quod genus est aliquid medium inter potentiam et actum, et quia comparatio

1 simpliciter ${ }^{1}$ ] om. Pc $\mathbf{2}$ communi] om. Vg $\mathbf{3}$ subiectis] substantiis Pg 4 maiorem om. $\mathrm{VgFc} \quad \mathbf{5}$ realis] realiter $\mathrm{Pg} \quad \mathbf{6}$ unitate] reali $a d d . \mathrm{Vg} \mid$ ut] et $\mathrm{Pj} \quad \mathbf{9}$ probationem ] probatio $\mathrm{Fb}$ | quod] om. FbPjVi $\mathbf{1 0}$ philosophi] si add. Vi | ita] ibi Vg | quod comparatio] om. $\mathrm{Vg}$ | sit] sic $\mathrm{Vg} \mathbf{1 1}$ generi] generari $\mathrm{FcN}$ | correspondet] corrumpit $\mathrm{Pg}$ 12 non] om. $\mathrm{N} 13$ potissimae] positivae $\mathrm{Pg} \mid$ probant] probant add. $\mathrm{Fb} \mid$ genere] generatione $\mathrm{N} \mathbf{1 4}$ secundum] sed $\mathrm{N} \quad 20$ unum] om. Vg | generis] om. FcPcVgVi 21 quare] om. $\mathrm{Fb}$ | sic] om. $\mathrm{FbNPj} 23$ qui] quod $\mathrm{Vg}$ | sequitur] speciem add. $\mathrm{FbFcN}$ $\mathrm{PcPjVg}$ speciem sed $a d d$. Vi 26 semper] per $\mathrm{Fb} 27$ simpliciter] singulariter $\mathrm{N}$ । et] om. Fc | hinc] hoc N 28 est] et Fc om. N 
est inter habentia unum concipi simpliciter. Ideo inter individua non est comparatio secundum genus.

[39] Ad illud de mensura dico quod mensura non accipitur secundum unitatem alicuius rei communis, sed tantum in intellectu et in concipi.

5 Et ideo intellectus facit illam mensurationem, quae metitur plura secundum unitatem aliquam quae est tantum in intellectu, licet proveniat a re mediante uno concipi, qui est per unum actum, qui provenit ab una specie, quam causant plura individua ratione unius impressionis quam apta nata sunt facere in intellectu.

10 [40] Ad argumentum in oppositum, cum dicitur quod per idem re non potest aliquid convenire cum alio et differre, respondeo: aut loqueris de convenientia et differentia formaliter. Et tunc concedo maiorem, quod per idem formaliter non possunt aliqua convenire et differre; quae enim conveniunt, conveniunt formaliter per relationem convenientiae, et

15 quae differunt, differunt formaliter per relationem mutuam differentiae. Quia ergo non est eadem relatio convenientia et differentia, ideo non eodem formali quo aliqua conveniunt differunt.

[41] Si vero loquaris non formaliter, sed fundamentaliter, tunc maior

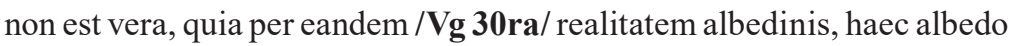

20 convenit magis cum hac albedine, et minus convenit cum /X 107a/ hac nigredine. Unde realitas eadem huius albedinis est illud quo haec albedo fundat convenientiam ad albedinem illam, et illud quo caret haec albedo tali gradu convenientiae /Pc 45va/ ad nigredinem ita quod ex parte fundamenti non est aliquis gradus distinctionis rei et rei, nec formalitatis et

25 formalitatis, sed per idem omnino convenit cum isto tantum, et cum alio non. Gradus autem distinctionis est tantum penes relationes convenientiae et disconvenientiae formaliter.

1 simpliciter] et add. NPgVi om. Vg 3 mensura ${ }^{1}$ m mensuratio $\mathrm{Vg} \mid$ non] om. $\mathrm{Vg}$ 5 quae] qui $\mathrm{PgFcVi} \quad \mathbf{6}$ licet] sed $\mathrm{Fb} \quad 7$ qui $^{1}$ ] quod $\mathrm{VgFc} \quad \mathbf{8}$ quam ${ }^{1}$ ] om. $\mathrm{N} \mid$ impressionis] impossibilis $\mathrm{N} \mid$ apta] acta $\mathrm{Vg} \mathbf{1 0}$ cum] quod Pc | cum dicitur] om. FcVg 11 cum alio] composito $N \quad 12$ concedo] concludo Pc 11-13 respondeo ... differre] om. N 13 differre] quia add. Vi 14 enim] etiam FcNPcPgPjVg; om. Vi | conveniunt $^{2}$ ] om $\mathrm{FcNPcPg} 15$ differunt $^{1}$ ] om. Fc 16 ideo] immo Pg igitur Vi 17 differunt] differentia $\mathrm{N} \mid$ albedo] om. $\mathrm{N} \quad 20$ convenit $^{2}$ ] concludit $\mathrm{Pc}$ 19-21 haec... nigredine] om. Fc 21-22 illud ... illud] om. Vg 23-24 fundamenti] fundati $a d d$. N 24-25 et formalitatis] om. Vi 26 non] tantum add. FbNPcPjVi 


\section{References}

\section{Manuscripts}

Firenze, Biblioteca nazionale centrale, ms. conv. soppr. A.3.120

Firenze, Biblioteca nazionale centrale, ms. conv. soppr. B.6.121

Napoli, Biblioteca nazionale, ms. VII.C.3

Padova, Biblioteca Antoniana, ms. 161 scaff. ix

Paris, Bibliothèque nationale de France, ms. latin 15867

Pelplin, Biblioteka Seminarium duchownego, ms. 46/85

Vaticano (Città del), Biblioteca Apostolica, ms. Borgiano 404

Vaticano (Città del), Biblioteca Apostolica, ms. Vat. lat. 942

\section{Primary Sources}

Aristoteles (1949). Analytica Posteriora. Ed. W.D. Ross. Oxford: Oxford University Press.

Aristoteles (1956). De Anima. Ed. W.D. Ross. Oxford: Oxford University Press.

Aristoteles (1982). De Generatione et Corruptione. Ed. C.J.F. Williams. Oxford: Oxford University Press

Aristoteles (1928). Metaphysica. Ed. W.D. Ross. Oxford: Clarendon Press.

Aristoteles (1936). Physica. Ed. W.D. Ross. Oxford: Clarendon Press.

Aristoteles (1963). Praedicamenta. Ed. J.L. Ackrill. Oxford: Clarendon Press.

Aristoteles Latinus (1968). Analytica posteriora. Translationes Iacobi, Anonymi sive 'Ioannis', Gerardi et Recensio Guillelmi de Moerbeka. Ed. L. Minio-Paluello, B.G. Dod. Bruges-Paris: Desclée De Brouwer.

Aristoteles Latinus (1984). De anima. Recensio Guillelmi de Morbeka. Ed. R.-A. Gauthier. In: Thomas de Aquino (1984), Sentencia libri De anima. Ed. R.-A. Gauthier. Roma-Paris: Editio Leonina.

Aristoteles Latinus (1986). De generatione et corruptione. Translatio Vetus. Ed. J. Judycka. Leiden: Brill.

Aristoteles Latinus (2003). De generatione et corruptione. Recensio Guillelmi de Morbeka. Ed. J. Judycka. Aristoteles Latinus Database. Turnhout: Brepols. 
Aristoteles Latinus (1961). Categoriae vel Praedicamenta. Translatio Boethii, Editio Composite, Translatio Guillelmi de Moerbeka, Lemmata e Simplicii commentario decerpta, Pseudo-Augustini Paraphrasis Themistiana. Ed. L. MinioPaluello. Bruges-Paris: Desclée De Brouwer.

Aristoteles Latinus (1995). Metaphysica, lib. I-XIV. Recensio et Translatio Guillelmi de Moerbeka. 2 vols. Ed. G. Vuillemin-Diem, Leiden: Brill.

Aristoteles Latinus (1990). Physica. Translatio Vetus. Ed. F. Bossier, J. Brams. Leiden: Brill.

Averroes (1953). Commentarium magnum in Aristotelis De anima libros. Ed. F.S. Crawford. In: H.A. Wolfson, D. Baneth, F.H. Fobes (ed.), Corpus Commentariorum Averrois in Aristotelem. Vol. 6. Cambridge: The Medieval Academy of America.

John Duns Scotus (1982). Lectura in Librum Secundum Sententiarum, dd. 1-6. Ed. L. Modrić, S. Bušelić, B. Hechich, I. Jurić, I. Percan, R. Rosini, S. Ruiz de Loizaga, C. Saco Alarcón. Vol. XVIII. Città del Vaticano: Typis Polyglottis Vaticanis.

John Duns Scotus (1973). Ordinatio Liber Secundus, dd. 1-3. Ed. C. Balić, C. Barbarić, S. Bušelić, B. Hechich, L. Modrić, S. Nanni, R. Rosini, S. Ruiz de Loizaga, C. Saco Alarcón. Vol. VII. Città del Vaticano: Typis Polyglottis Vaticanis.

John Duns Scotus (1997). Quaestiones super libros Metaphysicorum Aristotelis. Ed. R. Andrews, G. Etzkorn, G. Gál, R. Green, F. Kelley, G. Marcil, T. Noone, R. Wood. Opera Philosophica. Vol. IV. New York: St. Bonaventure.

John Wycliff (2017). De Scientia Dei. Ed. Campi. Oxford: Oxford University Press.

Les Auctoritates Aristotelis (1974). Ed. J. Hamesse. Louvain: Béatrice-Nauwelaerts.

Petrus Aureoli (1952-1956). Peter Aureoli Scriptum Super Primum Sententiarum. Ed. E. Buytaert. Vol. I-II. New York: St. Bonaventure.

Petrus Aureoli (1596). Commentariorum in Primum Librum Sententiarum. Pars prima. Auctore Petro Aureolo Verberio Ordinis Minorum Archiespiscopi Aquensi S. R. E. Cardinali, Ad Clementem VIII Pont. Opt. Max. Roma: Typographia Vaticana.

Petrus Aureoli (1605). Commentarii in Secundum Librum Sententiarum, ed. Petri Aureoli Verberii Ordinis Minorum Archiepiscopi Aquensis S.R.E. Cardinalis Commentariorum in Secundum Librum Sententiarum. Vol. 2. Roma: Typographia Alojsii Zannetti. 
Petrus Aureoli. II Sententiarum, d. 3, q. 2, art. 4. Firenze, Biblioteca nazionale centrale, ms. conv. soppr. A.3.120, ff. $25 \mathrm{va}-27 \mathrm{vb}$.

Petrus Aureoli (2005). Scriptum Super Primum Sententiarum, d. 23, art. 2. Ed. L.M. De Rijk. In: L.M. De Rijk, Giraldus Odonis O.F.M. Opera Philosophica. Vol. II: De Intentionibus. Critical Edition with a Study of the Medieval Intentionality Debate up to Ca. 1350. (pp. 695-748). Leiden: Brill.

Petrus Aureoli (2020). Petri Auriol Scriptum auper primum Sententiarum. The Electronic Scriptum. Ed. R.L. Friedman, L.O. Nielsen, C. Schabel. Retrieved from: http://www.peterauriol.net/editions/electronicscriptum/contents.

Roger Bacon (1930). Quaestiones supra libros primae philosophiae Aristotelis. Metaphysica $(I, I I, V-X)$. Ed. R. Steele. Oxford: E Typographeo Clarendoniano.

Simplicius (1907). Simplicii In Aristotelis Categorias commentarium. Ed. K. Kalbfleisch. Berlin: Typis et Impensis Georgii Reimeri.

Simplicius (1971-1975). Simplicius in Categorias. Ed. A. Pattin. CLC 5. Turnhout: Brepols.

Thomas Wylton (2003). Quodlibet, q. 5. Ed. L.O. Nielsen, T. Noone, C. Trifogli. In: Thomas Wylton's Question on the Formal Distinction as Applied to the Divine. Documenti e studi sulla tradizione filosofica medievale, 14, 327-388.

Thomas Wylton (2010). On the Intellectual Soul. Ed. L.O. Nielsen, C. Trifogli. Oxford: Oxford University Press.

Walter Burley. Expositio libri De anima, lib. I, q. 3. Città del Vaticano, Biblioteca Apostolica Vaticana, ms. Vat. lat. 2151, ff. 1ra-88rb.

\section{Secondary Sources}

Adriaenssen, H.Th. (2014). Peter John Olivi and Peter Auriol on Conceptual Thought. Oxford Studies in Medieval Philosophy, 2, 67-97.

Cenci, C. (1978). Manoscritti francescani della Biblioteca nazionale di Napoli. Vol. 1. Florence: Quaracchi.

Conti, A.D. (2000). Divine Ideas and Exemplar Causality in Auriol. Vivarium, 38, 99-116.

Conti, A.D. (2016). Walter Burley. In: E.N. Zalta (ed.), The Stanford Encyclopedia of Philosophy. Retrieved from: https://plato.stanford.edu/archives/ sum2016/entries/burley. 
Doucet, V. (1936). L'oeuvre scolastique de Richard de Conington. Archivum Franciscanum Historicum, 29, 396-442.

Davenport, A. (2006). Esse Egressus and Esse Apparens in Peter Auriol's Theory of Intentional Being. Mediaevalia Philosophica Polonorum, XXXV, 60-84.

Duba, W., Schabel, C. (2017). Remigio, Auriol, Scotus, and the Myth of the TwoYear-Sentences Lecture at Paris. Recherches de Théologie et Philosophie Médiévales, 84 (1), 143-179.

Fornasieri, G. (2018). Peter Auriol on Connotative Distinction and His Criticism of Scotus's Formal Distinction. Documenti e studi sulla tradizione filosofica medievale, 29, 231-273.

Fornasieri, G. (2019). Teoria degli universali e conoscenza della realtà in Pietro Aureoli. PhD Dissertation. Università degli Studi di Salerno-KU Leuven. Unpublished.

Fornasieri, G. (2021). Intelligere formaliter solum connotat aliquid ut apparens. Peter Auriol on the Nature of the Cognitive Act. Rivista di Storia della Filosofia, $1,24-49$.

Friedman, R.L. (1997). Conceiving and Modifying Reality: Some Modist Roots of Peter Auriol's Theory of Concept Formation. In: C. Marmo (ed.), Vestigia, Imagines, Verba: Semiotics and Logic in Medieval Theological Texts (XII-XIV Century) (pp. 305-321). Turnhout: Brepols.

Friedman, R.L. (1999). Peter Auriol on Intentions and Essential Predication. In: S. Ebbesen, R.L. Friedman (eds.), Medieval Analyses in Language and Cognition (pp. 415-430). Copenhagen: The Royal Danish Academy of Sciences and Letters.

Friedman, R.L. (2000). Peter Auriol on Intellectual Cognition of Singulars. Vivarium, $38,177-193$.

Friedman, R.L. (2013). Intellectual Traditions at the Medieval University: The Use of Philosophical Psychology in Trinitarian Theology among the Franciscans and Dominicans, 1250-1350. 2 vols. Leiden: Brill.

Friedman, R.L. (2015). Act, Species, and Appearance: Peter Auriol on Intellectual Cognition and Consciousness. In: G. Klima (ed.), Intentionality, Cognition, and Mental Representation in Medieval Philosophy (pp. 141-165). New York: Fordham University Press.

Goris, W. (2002). Implicit Knowledge-Being as First Known in Peter of Oriel. Recherches de Théologie et Philosophie Médiévales, 69 (1), 33-65. 
Halverson, J.L. (1998). Peter Aureol on Predestination: A Challenge to Late Medieval Thought. Leiden: Brill.

Marangon, P. (1997). Le origini e le fonti dello scotismo padovano. In: P. Marangon, Ad cognitionem scientiae festinare: gli studi nell'Università e nei conventi di Padova nei secoli XIII e XIV (pp. 178-230). Trieste: Edizioni Lint.

Mazurek, A., Ott, J. (2011). Die mittelalterlichen Handschriften der Signaturengruppe B in der Universitäts- und Landesbibliothek Düsseldorf. Teil 2. Ms. B 101a bis B 214 (pp. 213-215). Wiesbaden: Harrassowitz.

Paladini, C. (2018a). Essere ed essenza secondo Pietro Aureoli. Documenti e studi sulla tradizione filosofica medievale, 29, 275-330.

Paladini, C. (2018b). "Omnis res, eo quod est, singularis est." Pietro Aureoli sulla composizione metafisica dell'ente singolare. Rivista di Storia della Filosofia, 4, 569-593.

Pickavé, M. (2017). Peter Auriol and William of Ockham on a Medieval Version of the Argument from Illusion. In: J. Pelletier, M. Roques (eds.), The Language of Thought in Late Medieval Philosophy. Essays in Honor of Claude Panaccio (pp. 183-198). Berlin: Springer.

Rode, C. (2017). Peter Auriol on Universals and the Notion of Passive Conception. In: F. Amerini, L. Cesalli (eds.), Universals in the Fourteenth Century (pp. 138-154). Pisa: Edizioni della Normale.

Schabel, C. (2000). Place, Space, and the Physics of Grace in Auriol's Sentences Commentary. Vivarium, 38, 117-161.

Suarez-Nani, T. (2009). Singularité et individualité selon Pierre Auriol. In: S.F. Brown, T. Dewender, T. Kobusch (eds.), Philosophical Debates at Paris in the Early Fourteenth Century (pp. 339-357). Leiden: Brill.

Taieb, H. (2018). What is Cognition? Peter Auriol Account. Recherches de Théologie et Philosophie Médiévales, 85 (1), 109-134.

Teetaert, A. (1935). Pierre Auriol. In: É. Amann, E. Mangenot, A. Vacant (eds.), Dictionnaire de théologie catholique (pp. 1810-1881). Paris: Letouzey et Ané.

Wöller, F. (2015). Theologie und Wissenschaft bei Petrus Aureoli. Ein scholastischer Entwurf aus dem frühen 14. Jahrhundert. Leiden: Brill. 


\begin{abstract}
This paper comprises two parts. The first part is an introduction to Auriol's moderate conceptualism, as it is presented in his Commentary on Book II of the Sentences, distinction 9, question 2, article 1. The second part is an edition of the text. In the introduction, I focus on Auriol's use of the noetic tool of connotation. My thesis, in particular, is that connotation is a necessary prerequisite to his moderate conceptualism. To this purpose, the first part of this introduction will be devoted to a brief presentation of Auriol's conceptualism. In the second part, Auriol's theory of essential predication will be presented. In the third part, I will present my claim that Auriol's theory of essential predication can only be made sense of when read against the background of his theory of connotation as applied to intellectual cognition. Finally, I will offer a collation of Auriol's Commentary on Book II of the Sentences, distinction 9 , question 2 , article 1 , obtained by collating eight manuscripts, which hand down Auriol's text, that is, Firenze, Biblioteca nazionale centrale, ms. Conv. Soppr. B.6.121, Firenze, ms. Conv. Soppr. A. 3.120, Napoli, Biblioteca nazionale, ms. VII.C.3, Padova, Biblioteca Antoniana, ms. 161, scaff. ix, Paris, Bibliothèque nationale de France, ms. latin 15867; Pelplin, Biblioteka Seminarium duchownego, ms. 46/85, Vaticano (Città del), Biblioteca Apostolica, ms. Borgiano 404, Vaticano (Città del), Biblioteca Apostolica, ms. Vat. lat. 942.
\end{abstract}

